\title{
Analysis of Internet Addiction Levels of Primary School, Secondary School and High School Senior Students
}

\section{Research Article}

\author{
Hasan AYDEMIR ${ }^{1}$, Mustafa CINAR ${ }^{2}$, Yalcin KARALI ${ }^{3}$ \\ ${ }^{1}$ İnönü University, Faculty of Education, Department of Basic Education, Malatya, Turkey, ORCID: 0000-0002-3073-9194 \\ ${ }^{2}$ Firat University, Institute of Education Sciences, Elazı̆̆, Turkey, ORCID: 0000-0001-5309-5427 \\ '̇ंnönü University, Faculty of Education, Department of Basic Education, Malatya, Turkey, ORCID: 0000-0002-8977-5034
}

To cite this article: Aydemir, H., \& Cinar, M., \& Karali, Y. (2021). Analysis of internet addiction levels of primary school, secondary school and high school senior students, International Online Journal of Educational Sciences, 13(4), 1152-1178.

\begin{abstract}
ARTICLE INFO
ABSTRACT

Article History:

Received: 26.02.2021

Available online:

24.08.2021

In this study, Internet addiction status of primary, secondary, and high school senior students studying in Yeşilyurt district of Malatya province were analyzed according to various variables. The population of the study consisted of 11,868 students from state schools in Yeşilyurt District of Malatya Province, and the study sample was composed of 2,611 students. The research has the relational screening model. In the study, "Internet Addiction Scale" developed by Günüç (2009) was used to determine the Internet addiction levels of students. This scale consists of the sub-dimensions of "deprivation", "control difficulty", "impairment in functionality" and "social isolation." In the analysis of the data obtained, t-test, k-means cluster analysis, one-way analysis of variance (One-Way ANOVA) test were used. "LSD", one of the "post-hoc" techniques, was applied to determine which group or groups the difference originated from in cases where there was significant differentiation as a result of the "ANOVA" test. In summary, the following findings were reached in the study: Of the 2,611 students, 397 (15.2\%) were in the addicted group, 1,016 (38.9\%) in the risk group, and 1,198 $(45.9 \%)$ in the non-addicted group. When these results are taken into consideration, it is seen that most of the students that made up the sample were in the "non-addicted group" (45.9\%). A significant difference was found in favor of male students between students' mean scores for Internet addiction according to their gender. A significant difference in favor of senior high school students was found between the levels of the schools where the students' studies and their Internet addiction mean scores. There was no significant difference between the mean Internet addiction scores of the students according to their mother's education level, father's education level, mother and father's profession, and the monthly income of the family.
\end{abstract}

(C) 2021 IOJES. All rights reserved

Keywords:

Addiction, Internet addiction, Primary school, Secondary school, High school

\footnotetext{
${ }^{1}$ Corresponding author's address: İnönü University, Faculty of Education MALATYA 


\section{Introduction}

The Internet, which has been developing and changing globally since its inception, has affected our lives on a large scale and paved the way for advances in many areas. The Internet has become an indispensable situation in today's world by strongly making its presence felt in many areas such as economy, education, art, science, and daily life. The benefits of the Internet and its reflections on our daily lives are countless. However, Internet technology has also led to the development of some negative behaviors. Internet addiction is the leading one among these problems.

In general, addiction and substance use are thought to fulfill the function of helping the individual overcome the difficulties in daily life. (Flores, 2004, s. 1). Addiction, which often refers to behavioral routines to obtain chemicals and sometimes without purpose, is a psychiatric disorder in which the individual exhibits recurring obsessions or behaviors based on the feeling of obligation (Marks, 1990, s. 1389). Although addiction is traditionally seen as a phenomenon caused by only stimulant substances that affect human behavior such as alcohol or cocaine, studies conducted in the last 30 years have shown that individuals can also be harmed by behaviors and habits that show signs of addiction. Binge eating, gambling, shopping, sex and Internet use can also create problems similar to stimulant substances (Padwa \& Cunningham, 2010, p. 1). Therefore, the concept of addiction has been increasingly used to explain many human behaviors as well (Netherland, 2012, p.11).

Technology addiction, which is defined as a type of non-chemical addiction involving human and machine interaction when computers are used extensively, was first mentioned by Griffiths (1995, p. 14,15). With the spread of the Internet around the world since the mid-1990s, Internet addiction has been defined as an important legal psychological disorder affecting the cognitive, emotional, and social development of individuals (Price, 2011, p. 7). As early as 1998, it was determined that $6 \%$ of online users faced this problem in the United States (Brenner, 2000, p. 452). However, unlike chemical addiction, excessive Internet use has come to the fore with some technological benefits it provides to society, rather than being criticized for being addictive (Young, 2009, p.217). When the first symptoms of Internet addiction emerged, it caused controversy among clinicians and academics. Excessive Internet use has been accepted by some as pathological and addictive, and a type of technological addiction (Widyanto \& Griffiths, 2006, p.31).

Internet use, which is one of the realities of the information age, has affected almost every aspect of life as well as the education and school system and the structure of education planning. The Internet not only has made access to information cheaper and easier, but also rendered information independent of time and place. As a natural consequence of this, access to information seems to be no longer a problem (Aydemir et al., 2013, p. 1073). The proper definition of the concept of Internet addiction has varied according to different perspectives. It has been characterized by impulses or behaviors related to computer and Internet use that generally cause uncontrollable engagement as well as disruption and distress (Shaw and Black, 2008, p. 353). Some researchers have associated Internet addiction with addictions involving alcohol and substance use (Griffiths, 1999, p. 246), while others have affiliated it with the individual's recurrent obsessions or compulsive control disorders (Belsare, Gaffney, and Black, 1997). Terms such as pathological Internet use (Davis, 2001, p. 187), and problematic Internet use (Caplan, 2003, p. 625) have also been used to define this problem.

The concept of Internet addiction, which is one of the last links in the chain of technology addiction, was first addressed by Ivan Goldberg (Suler, 1999). Internet addiction is a process that cannot be controlled, takes a significant amount of time, and results in problematic social or professional difficulties (Shapira et al., 2000, p. 268). According to Young (2004), Internet addiction as a rapidly growing phenomenon is a concept that includes a wide range of behaviors and impulse control problems associated with gambling addiction ( $p$. 402). Griffiths (1999) stated that the Internet may not be addictive for most of the extreme users, and that it can also be a means of satisfying other addictions. 
The number of Internet users worldwide, which was 360 million in 2000 (Internet World Status [IWS], 2017) exceeded 4.02 billion individuals in 2018. (Bayrak, 2018). According to data from 2020, in Turkey, the rate of Internet use for individuals in the 16-74 age group was 79\% (Turkey Statistics Institute [TUIK], 2020). The number of users in all age groups has been recorded as approximately 70 million people (IWS, 2020). With the increase in the place of the Internet in daily life in this way, the relationship between Internet addiction and many variables, especially psychological factors, has been investigated. In these studies, it has been determined that there is a relationship between problematic Internet use and attention deficit and hyperactivity disorder ( Dalbudak and Evren, 2013; Ko, 2009; Öztürk et al., 2013; Yen et al., 2007 ) , depression (Choi et al., 2014; Koronczai et al., 2013; Şahin et al., 2013; Şenormancı et al., 2014; Yang et al., 2014), loneliness (Yao and Zhong, 2014), neurotic personality (Tsai et al., 2009; Wang et al., 2011), low self-esteem (Armstrong, Phillips, and Saling, 2000; Aydın and Sarı, 2011; Sariyska et al., 2014), low self-control (Özdemir, Kuzucu, and Ak , 2014), academic failure (Stavropoulos, Alexandraki, and Stefanidi 2013), feelings of hostility (Koç, 2011), and sleep problems (Anderson, 2001; Lam, 2014).

With this study, it was aimed to reveal the Internet addiction status of students through the relevant literature and feedback received from students, and to contribute to the field by determining the relationships between Internet addiction and some demographic variables such as gender, school level, parents 'education level, parents' occupation and family monthly income.

\section{Method}

Screening model was used in the study. Since Internet addiction was examined according to various variables, it was determined to have a relational screening model. Screening models are the screening work performed on the whole of the universe or on a group, or a sample to be taken from it in order to make a general judgment about the universe in large-scale studies. (Karasar, 2011; p. 110).

\section{Population and Sample}

The universe of the study was composed of a total of 11,868 students receiving education in state schools located in Yeşilyurt District of Malatya Province, and 4,199 of them were senior students from 60 primary schools, 4,227 senior students from 56 secondary schools and 3,442 senior students from 37 high schools. The sample of the study was chosen randomly among the schools in the universe, and it consisted of a total of 2,986 students, including 1,326 senior students from 35 primary schools, 859 senior students from 24 secondary schools, and 799 senior students from 17 high schools. Out of the 2,986 students reached, 2611 were evaluated.

Information on the distribution of students according to their demographic characteristics is given in Table 1 as frequency and percentage.

Table 1. Demographic Characteristics of the Students

\begin{tabular}{|c|c|c|c|c|}
\hline Variable & Options & & Frequency (f) & Percentage $(\%)$ \\
\hline \multirow{3}{*}{ Gender } & Female & & 1,324 & 50.7 \\
\hline & Male & & 1,287 & 49.3 \\
\hline & & Total & 2,611 & 100 \\
\hline \multirow{4}{*}{ School } & Primary school & & 1,216 & 46.6 \\
\hline & Secondary School & & 789 & 30.2 \\
\hline & High School & & 606 & 23.2 \\
\hline & & Total & 2,611 & 100 \\
\hline \multirow{4}{*}{ Education Status of the Mother } & Literate & & 199 & 7.6 \\
\hline & Primary school & & 679 & 26.0 \\
\hline & Secondary School & & 596 & 22.8 \\
\hline & High School & & 691 & 26.5 \\
\hline
\end{tabular}




\begin{tabular}{llccc} 
& University & & 446 & 17.1 \\
& & Total & $\mathbf{2 , 6 1 1}$ & $\mathbf{1 0 0}$ \\
\hline \multirow{4}{*}{ Father's Level of Education } & Literate & 65 & 2.5 \\
& Primary school & 344 & 13.2 \\
& Secondary School & & 501 & 19.2 \\
& High School & & 931 & 35.7 \\
& University & & 768 & 29.4 \\
& & Total & $\mathbf{2 , 6 1 1}$ & $\mathbf{1 0 0}$ \\
\hline \multirow{3}{*}{ Mother's Occupation } & Civil Servant & & 316 & 12.1 \\
& Worker & & 382 & 14.6 \\
& Housewife & & 1,913 & 73.3 \\
& & Total & $\mathbf{2 , 6 1 1}$ & $\mathbf{1 0 0}$ \\
\hline \multirow{3}{*}{ Father's Occupation } & Civil Servant & & 791 & 30.3 \\
& Retired & & 201 & 7.7 \\
& Worker & & 619 & 23.7 \\
& Craftsman & & 466 & 17.8 \\
& Farmer & & 534 & 20.5 \\
& & Total & $\mathbf{2 , 6 1 1}$ & $\mathbf{1 0 0}$ \\
\hline \multirow{3}{*}{ Family's Monthly Income } & 0-1,500 TL & & 729 & 27.9 \\
& 1,501-3,000 TL & & 1,045 & 40.0 \\
& 3,001-4,500 TL & & 488 & 18.7 \\
& 4,501 TL and above & 349 & 13.4 \\
& & Total & $\mathbf{2 , 6 1 1}$ & $\mathbf{1 0 0}$ \\
\hline & & &
\end{tabular}

\section{Data Collection Tool}

In the study, "Internet Addiction Scale" developed by Günüç (2009) was used in order to determine the Internet addiction levels of the students. The scale is a 35-item scale consisting of the subdimensions of "deprivation", "difficulty in control", "impairment in functionality" and "social isolation." The scale is a 5-point Likert type scale, and all items in the scale are related to addiction. The internal consistency coefficient of the scale was calculated as $(\alpha) .944$. Cronbach's alpha reliability coefficients of the 4 subdimensions $(\alpha)$ were found to be .877 for the 11-item deprivation subdimension, .855 for the 10-item difficulty in control subdimension, .827 for the 7-item impairment in functionality subdimension, and .791 for the 7-item social isolation subdimension. The item discrimination levels for the subdimensions were found as between .477-.681, .471$.606, .520-.618$, and .463-.615 for the first, second, third and fourth subdimensions, respectively.

\section{Data Analysis}

In the study, the data obtained from the participants were analyzed using the licensed SPSS (The Statistical Package for Social Sciences) 22.0 package program. After the data obtained from the scales were transferred to the computer environment, normality test was performed to determine whether the data complied with normal distribution. In a statistical study, the distribution should be normal or close to normal in order to perform many tests (Kalayc1, 2006). Although many features in the universe show a normal distribution, there will be deviations from the normal distribution if the measurements of a feature that is tried to be determined are obtained from a small group $(\mathrm{n}<30)$. As the size of the group increases, the distribution will approach normality (Ravid, 1994, as cited in Büyüköztürk, 2011; p. 63). Tabachnick and Fidell (2007) consider the distribution as the normal distribution when the skewness and kurtosis values are between +1.500 and -1.500. As a result of the normality test applied, since the skewness (.762) and kurtosis (.074) values of the scale items were found to be between +1.500 and -1.500 , it can be said that the distribution was normal. 
Descriptive statistics were used in the analysis of the data obtained in the study. Frequency distributions, kmeans cluster analysis, t-test, and One-Way ANOVA were used for the analysis of the sub-problems of the study. In the case of determination of a significant difference as a result of one-way analysis of variance, LSD test was used to determine which groups caused the difference, if the variances were equal. In the analysis of the data, the significance value was accepted as $(\mathrm{p}<.05)$.

The "cluster analysis" technique, one of the sampling classification techniques, was applied in order to obtain more detailed results about the addiction status of individuals by determining the group with or without Internet addiction. The general purpose of cluster analysis is to reveal the similarities of units according to their specific characteristics, and to classify them in correct categories based on these similarities (Çokluk et al., 2014, p.139). With cluster analysis, it was aimed to reveal some extreme individuals who were latent in the sample (Günüç and Kayri, 2009, p. 171), and thus to classify the addiction levels of individuals in a healthier way. Many algorithms have been proposed for cluster analysis in the literature. However, it is possible to group them under two main headings. These are 'hierarchical clustering methods' and 'nonhierarchical clustering methods' (Çokluk et al., 2014, p.139). Hierarchical clustering methods are particularly suitable for small samples (generally $\mathrm{n}<250$ ) (Hair et al., 2006). Non-hierarchical clustering methods are used when the number of clusters has been determined. In other words, it is recommended to be used in cases where the researcher has prior knowledge about the number of clusters or when the number of clusters has been determined (Özdamar, 2010).

The K-Means Cluster Analysis, one of the non-hierarchical clustering methods, was employed to obtain a more detailed analysis of individuals' Internet addiction. Accordingly, as seen in Table 2, the first cluster includes the "addicted group", the second cluster consists of the "group with risk of addiction", and the third cluster includes the "non-addicted group." The thesis written by Günüç (2009) was taken as an example in naming the clusters.

\section{Findings}

\section{Findings Related to the Students' Internet Addiction Status}

The frequency and percentage distributions regarding the Internet addiction levels of primary, secondary, and high school senior students according to the scores obtained from the total scale are given in Table 2.

Table 2. Frequency and Percentage Values Regarding the Students' Internet Addiction Status

\begin{tabular}{|c|c|c|c|c|}
\hline & Clustering (k-means) & & $\mathbf{F}$ & Total (\%) \\
\hline \multirow{4}{*}{ 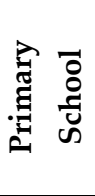 } & 1 (Addicted Group) & & 185 & 15.3 \\
\hline & 2 (Risk Group) & & 452 & 37.1 \\
\hline & 3 (Non-Addicted Group) & & 578 & 47.6 \\
\hline & & Total & 1,216 & 100 \\
\hline \multirow{4}{*}{ 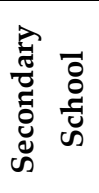 } & 1 (Addicted Group) & & 102 & 12.9 \\
\hline & 2 (Risk Group) & & 300 & 38.0 \\
\hline & 3 (Non-Addicted Group) & & 386 & 49.1 \\
\hline & & Total & 789 & 100 \\
\hline \multirow{4}{*}{ 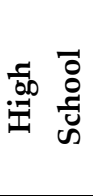 } & 1 (Addicted Group) & & 85 & 14.1 \\
\hline & 2 (Risk Group) & & 258 & 42.6 \\
\hline & 3 (Non-Addicted Group) & & 262 & 43.3 \\
\hline & & Total & 606 & 100 \\
\hline \multirow{4}{*}{ "त⿱艹兀) } & 1 (Addicted Group) & & 397 & 15.2 \\
\hline & 2 (Risk Group) & & 1,016 & 38.9 \\
\hline & 3 (Non-Addicted Group) & & 1,198 & 45.9 \\
\hline & & Total & 2,611 & 100 \\
\hline
\end{tabular}


When Table 2 is examined, it is seen that out of 2,611 students, 397 (15.2\%) were in the addicted group, $1,016(38.9 \%)$ were in the risk group, and 1,198 (45.9\%) were in the non-addicted group. It is seen that most of the students in the sample were in the "non-addicted group" (45.9\%).

\section{Findings Regarding Gender}

The results of the t-test conducted to determine whether there was a significant difference between the Internet addiction scores of the students in terms of their gender are shown in Table 3.

Table 3. T-test Findings Regarding the Students' Internet Addiction in Terms of Gender

\begin{tabular}{|c|c|c|c|c|c|c|}
\hline Subdimensions & Gender & $\mathbf{N}$ & $\bar{X}$ & Sd & $\mathbf{t}$ & $\mathrm{p}$ \\
\hline \multirow{2}{*}{ Deprivation } & Female & 1,324 & 2.48 & 0.97 & \multirow{2}{*}{1.88} & \multirow{2}{*}{$.00^{*}$} \\
\hline & Male & 1,287 & 2.65 & 1.02 & & \\
\hline \multirow{2}{*}{ Difficulty in Control } & Female & 1,324 & 2.02 & 0.89 & \multirow{2}{*}{3.45} & \multirow{2}{*}{$.00^{*}$} \\
\hline & Male & 1,287 & 2.16 & 0.95 & & \\
\hline Impairment in & Female & 1,324 & 1.97 & 0.95 & \multirow{2}{*}{2.83} & \multirow{2}{*}{$.00^{*}$} \\
\hline Functionality & Male & 1,287 & 2.09 & 0.98 & & \\
\hline \multirow{2}{*}{ Social Isolation } & Female & 1,324 & 1.92 & 0.96 & \multirow{2}{*}{0.06} & \multirow{2}{*}{$.01^{*}$} \\
\hline & Female & 1,287 & 2.01 & 0.95 & & \\
\hline Internet Addiction & Female & 1,324 & 2.13 & 0.82 & \multirow{2}{*}{2.48} & \multirow{2}{*}{$.00^{*}$} \\
\hline Scale (Total) & Male & 1,287 & 2.27 & 0.85 & & \\
\hline
\end{tabular}

$\mathrm{N}=\mathbf{2 6 1 1}$

When Table 3 is examined, it is seen that there were significant differences in favor of male students in terms of gender in the total scale and in all sub-dimensions of the Internet addiction scale $(\mathrm{p}<0.05)$.

\section{Findings Regarding the School Level}

The results of one-way analysis of variance regarding the Internet addiction scores of the students according to their school levels are shown in Table 4.

Table 4. One-Way Anova Results Regarding the Students' Internet Addiction Scores According to Their School Level

\begin{tabular}{|c|c|c|c|c|c|c|c|}
\hline Subdimensions & Grade & $\begin{array}{l}\text { Sum of } \\
\text { Squares }\end{array}$ & Sd & $\begin{array}{c}\text { Mean } \\
\text { Square }\end{array}$ & $\mathbf{F}$ & $\mathrm{p}^{*}$ & $\begin{array}{c}\text { Significant } \\
\text { Difference (LSD) }\end{array}$ \\
\hline \multirow{3}{*}{ Deprivation } & Intergroup & 3.41 & 2 & 1.70 & 1.69 & .18 & \\
\hline & Intragroup & 2630.72 & 2607 & 1.00 & & & \\
\hline & Total & 2634.13 & 2609 & & & & \\
\hline \multirow{3}{*}{$\begin{array}{r}\text { Difficulty in } \\
\text { Control }\end{array}$} & Intergroup & 30.32 & 2 & 15.16 & 17.86 & $.00^{*}$ & \\
\hline & Intragroup & 2213.60 & 2608 & 0.84 & & & High School - 2.28 \\
\hline & Total & 2243.93 & 2610 & & & & \\
\hline \multirow{3}{*}{$\begin{array}{l}\text { Impairment in } \\
\text { Functionality }\end{array}$} & Intergroup & 35.19 & 2 & 17.59 & 18.96 & $.00 *$ & \\
\hline & Intragroup & 2417.63 & 252 & 0.92 & & & High School - 2.24 \\
\hline & Total & 2452.82 & 2608 & & & & \\
\hline \multirow{3}{*}{ Social Isolation } & Intergroup & 76.61 & 2 & 38.30 & 42.55 & $.00^{*}$ & \\
\hline & Intragroup & 2347.65 & 2608 & 0.90 & & & High School - 2.27 \\
\hline & Total & 2424.27 & 2610 & & & & \\
\hline Internet & Intergroup & 20.55 & 2 & 10.27 & 14.63 & $.00^{*}$ & \\
\hline Addiction Scale & Intragroup & 1829.01 & 2605 & 0.70 & & & High School - 2.36 \\
\hline (Total) & Total & 1849.56 & 2607 & & & & \\
\hline
\end{tabular}


When Table 4 is analyzed, it is seen that there was a significant difference according to the school levels of the students. As a result of the LSD test, a significant difference was observed in favor of high school senior students. When the subdimensions of the Internet addiction scale were examined, a significant difference was observed in favor of high school senior students in the subdimensions "difficulty in control", "impaired functionality" and "social isolation" ( $\mathrm{p}<0.05)$.

\section{Findings Regarding the Education Status of the Mothers}

The results of one-way analysis of variance regarding the Internet addiction scores of the students according to the education levels of the mothers are shown in Table 5.

Table 5. One-Way Anova Results Regarding the Students' Internet Addiction Scores According to the Education Status of the Mothers

\begin{tabular}{|c|c|c|c|c|c|c|}
\hline \multirow[b]{2}{*}{ Subdimensions } & \multicolumn{3}{|l|}{ Education Status of the } & \multicolumn{3}{|l|}{ Mean } \\
\hline & Mother & Sum of Squares & Sd & Square & $\mathbf{F}$ & $\mathrm{p}$ \\
\hline \multirow{3}{*}{ Deprivation } & Intergroup & 24.53 & 4 & 4.09 & & \\
\hline & Intragroup & 2609.59 & 2603 & 1.00 & 4.07 & .06 \\
\hline & Total & 2634.13 & 2607 & & & \\
\hline \multirow{3}{*}{ Difficulty in Control } & Intergroup & 13.80 & 4 & 2.30 & & \\
\hline & Intragroup & 2230.12 & 2602 & 0.85 & 2.68 & .13 \\
\hline & Total & 2243.93 & 2606 & & & \\
\hline Impairment in & Intergroup & 10.31 & 4 & 1.71 & & \\
\hline \multirow[t]{2}{*}{ Functionality } & Intragroup & 2442.50 & 2602 & 0.93 & 1.83 & .89 \\
\hline & Total & 2452.82 & 2606 & & & \\
\hline \multirow{3}{*}{ Social Isolation } & Intergroup & 15.05 & 4 & 0.14 & & \\
\hline & Intragroup & 2409.21 & 2604 & 0.43 & 0.32 & .85 \\
\hline & Total & 2424.27 & 2608 & & & \\
\hline \multirow{3}{*}{$\begin{array}{l}\text { Internet Addiction } \\
\text { Scale (Total) }\end{array}$} & Intergroup & 15.06 & 4 & 2.51 & & 07 \\
\hline & Intragroup & 1834.50 & 2601 & 0.70 & 3.55 & .07 \\
\hline & Total & 1849.56 & 2605 & & & \\
\hline
\end{tabular}

According to Table 5, no significant difference was observed in the Internet addiction total scale and in all its subdimensions according to the education status of the students' mothers.

\section{Findings Regarding the Education Status of the Fathers}

The results of one-way analysis of variance regarding the Internet addiction scores of the students according to the education level of the fathers are shown in Table 6.

Table 6. One-Way Anova Results Regarding the Students' Internet Addiction Scores According to the Education Status of the Fathers

\begin{tabular}{|c|c|c|c|c|c|c|}
\hline \multirow[b]{2}{*}{ Subdimensions } & \multicolumn{6}{|l|}{ Education Status of the } \\
\hline & Father & Sum of Squares & Sd & Mean Square & $\mathbf{F}$ & $\mathrm{p}$ \\
\hline \multirow{3}{*}{ Deprivation } & Intergroup & 23.53 & 4 & 3.92 & & \\
\hline & Intragroup & 2609.82 & 2604 & 1.00 & 3.91 & .10 \\
\hline & Total & 2633.35 & 2608 & & & \\
\hline \multirow{3}{*}{ Difficulty in Control } & Intergroup & 6.90 & 4 & 1.15 & & \\
\hline & Intragroup & 2236.78 & 2605 & 0.85 & 1.33 & .23 \\
\hline & Total & 2243.69 & 2609 & & & \\
\hline \multirow{3}{*}{$\begin{array}{l}\text { Impairment in } \\
\text { Functionality }\end{array}$} & Intergroup & 7.79 & 4 & 1.29 & & \\
\hline & Intragroup & 2444.87 & 2603 & 0.94 & 1.38 & .21 \\
\hline & Total & 2452.66 & 2607 & & & \\
\hline & Intergroup & 10.05 & 4 & 1.67 & & \\
\hline
\end{tabular}




\begin{tabular}{|c|c|c|c|c|c|c|c|}
\hline \multirow{2}{*}{ Social Isolation } & \multirow[t]{2}{*}{ Intragroup } & \multirow[b]{2}{*}{ Total } & \multirow{2}{*}{$\begin{array}{l}2414.06 \\
\mathbf{2 4 2 4 . 1 1}\end{array}$} & \multirow{2}{*}{$\begin{array}{l}2602 \\
2606\end{array}$} & \multirow[t]{2}{*}{0.92} & \multirow{2}{*}{1.80} & \multirow{2}{*}{.09} \\
\hline & & & & & & & \\
\hline \multirow{3}{*}{$\begin{array}{l}\text { Internet Addiction } \\
\text { Scale (Total) }\end{array}$} & Intergroup & & 10.23 & 4 & 1.70 & & \\
\hline & Intragroup & & 1839.31 & 2602 & 0.70 & 2.41 & .25 \\
\hline & & Total & 1849.54 & 2606 & & & \\
\hline
\end{tabular}

When Table 6 is examined, it is seen that there was no significant difference in terms of fathers' education status of students in total scale and subdimensions of the Internet addiction scale.

\section{Findings Regarding the Mothers' Occupations}

The results of one-way analysis of variance regarding the Internet addiction scores of the students according to the mothers' occupations are shown in Table 7.

Table 7. One-Way Anova Results Regarding the Students' Internet Addiction Scores According to the Mothers' Occupations

\begin{tabular}{|c|c|c|c|c|c|c|c|}
\hline \multirow[b]{2}{*}{ Subdimensions } & \multicolumn{4}{|l|}{ Mother's } & \multicolumn{3}{|l|}{ Mean } \\
\hline & Occupation & & Sum of Squares & Sd & Square & $\mathbf{F}$ & $\mathrm{p}$ \\
\hline \multirow{3}{*}{ Deprivation } & Intergroup & & 2.31 & 2 & 0.33 & & \\
\hline & Intragroup & & 2631.82 & 2607 & 1.01 & 0.32 & .94 \\
\hline & & Total & 2634.13 & 2609 & & & \\
\hline \multirow{3}{*}{ Difficulty in Control } & Intergroup & & 3.75 & 2 & 0.53 & & \\
\hline & Intragroup & & 2240.17 & 2608 & 0.86 & 1.62 & .73 \\
\hline & & Total & 2243.93 & 2610 & & & \\
\hline \multirow{3}{*}{ Impairment in Functionality } & Intergroup & & 7.74 & 2 & 1.10 & & \\
\hline & Intragroup & & 2445.07 & 2606 & 0.94 & 1.17 & .31 \\
\hline & & Total & 2452.82 & 2608 & & & \\
\hline \multirow{3}{*}{ Social Isolation } & Intergroup & & 11.16 & 2 & 1.59 & & \\
\hline & Intragroup & & 2413.11 & 2608 & 0.92 & 1.72 & .10 \\
\hline & & Total & 2424.27 & 2610 & & & \\
\hline \multirow{3}{*}{ Internet Addiction Scale (Total) } & Intergroup & & 3.09 & 2 & 0.44 & & \\
\hline & Intragroup & & 1846.47 & 2605 & 0.71 & 0.62 & .73 \\
\hline & & Total & 1849.56 & 2607 & & & \\
\hline
\end{tabular}

As can be seen in Table 7, no significant difference was observed in the total Internet addiction scale and its subdimensions in terms of the students' mothers' occupations.

\section{Findings Regarding the Fathers' Occupations}

The results of one-way analysis of variance regarding the Internet addiction scores of the students according to the fathers' occupations are shown in Table 8.

Table 8. One-Way Anova Results Regarding the Students' Internet Addiction Scores According to the Fathers' Occupations

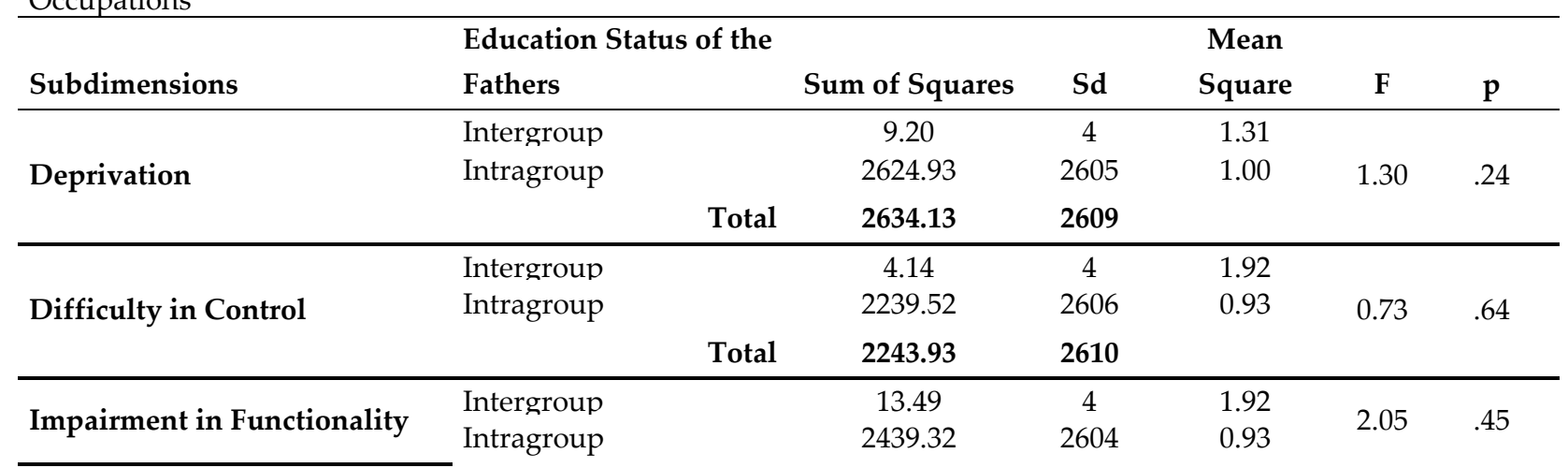




\begin{tabular}{|c|c|c|c|c|c|c|c|}
\hline & & Total & 2452.82 & 2608 & & & \\
\hline \multirow{3}{*}{ Social Isolation } & Intergroup & & 10.02 & 4 & 1.43 & & \\
\hline & Intragroup & & 2414.25 & 2606 & 0.92 & 1.54 & 0.14 \\
\hline & & Total & 2424.27 & 2610 & & & \\
\hline \multirow{3}{*}{$\begin{array}{l}\text { Internet Addiction Scale } \\
\text { (Total) }\end{array}$} & Intergroup & & 5.40 & 4 & 0.77 & & \\
\hline & Intragroup & & 1844.15 & 2603 & 0.70 & 1.08 & 36 \\
\hline & & Total & 1849.56 & 2607 & & & \\
\hline
\end{tabular}

When Table 8 is examined, it is seen that there was no significant difference for the total Internet addiction scale and its subdimensions according to the occupations of the students' fathers.

\section{Findings Regarding Family Monthly Income}

The results of one-way analysis of variance for Internet addiction scores according to the family monthly income of the students are shown in Table 9.

Table 9. One-Way Anova Results of Internet Addiction Scores of Students According to Family Monthly Income

\begin{tabular}{|c|c|c|c|c|c|c|c|}
\hline \multirow[b]{2}{*}{ Subdimensions } & \multirow[b]{2}{*}{ Income Level } & & \multirow[b]{2}{*}{ Sum of Squares } & \multicolumn{3}{|c|}{ Mean } & \multirow[b]{2}{*}{$\mathbf{p}$} \\
\hline & & & & Sd & Square & $\mathbf{F}$ & \\
\hline \multirow{3}{*}{ Deprivation } & Intergroup & & 32.91 & 3 & 3.65 & & \\
\hline & Intragroup & & 2601.21 & 2606 & 1.00 & 3.65 & .06 \\
\hline & & Total & 2634.13 & 2609 & & & \\
\hline \multirow{3}{*}{ Difficulty in Control } & Intergroup & & 15.66 & 3 & 1.74 & & \\
\hline & Intragroup & & 2228.27 & 2607 & 0.85 & 2.03 & .48 \\
\hline & & Total & 2243.93 & 2610 & & & \\
\hline \multirow{3}{*}{ Impairment in Functionality } & Intergroup & & 7.79 & 3 & 0.86 & & \\
\hline & Intragroup & & 2445.02 & 2605 & 0.94 & 2.85 & .50 \\
\hline & & Total & 2452.82 & 2608 & & & \\
\hline \multirow{3}{*}{ Social Isolation } & Intergroup & & 23.72 & 3 & 2.63 & & \\
\hline & Intragroup & & 2400.54 & 2607 & 0.92 & 2.85 & .08 \\
\hline & & Total & 2424.27 & 2610 & & & \\
\hline \multirow{3}{*}{$\begin{array}{l}\text { Internet Addiction Scale } \\
\text { (Total) }\end{array}$} & Intergroup & & 17.09 & 3 & 1.89 & & \\
\hline & Intragroup & & 1832.47 & 2604 & 0.70 & 2.69 & .22 \\
\hline & & Total & 1849.56 & 2607 & & & \\
\hline
\end{tabular}

In Table 9, no significant difference was observed in the total Internet addiction scale and its subdimensions according to the income level of the students' families.

\section{Discussion, Conclusion and Recommendations}

\section{Discussion}

In this study, it was aimed to determine the Internet addiction status of students and to identify its relationships with some demographic variables such as gender, school level, parents 'education status, parents' occupations and family monthly income. Different Internet addiction levels were determined in studies. Özdemir (2016) found this level as 1.5\%, İşleyen (2013) as 7\%, Günüç (2009) as 10.1\%, Inan (2010) as $0.4 \%$, Çalışgan (2013) as 0.2\%, Balcı and Gülnar (2009) as 23.2\%, Durualp and Çiçekçioğlu (2013) as 17\%, Yücelten (2016) and Döner (2011) as 0\%. In some other studies, these rates were found as 4\% (Wang et al.2011), as 1.1\%(Bayraktar, 2001), as 3.1\% (Kaltiala-Heino, Lintonen, and Rimpela, 2004), as 2\% (Johansson and Götestam, 2004), as 20.7\% (Yen et al., 2007), as 2.4\% (Cao and Su, 2007 ), as 8\% (Elizabeth and Tee, 2007), as $4.3 \%$ (Jang, Hwang, and Choi, 2008) (as cited in Günüç, 2009, p.89) .

The literature review showed that in Özdemir's (2016) study, 14\% of the sample were Internet users in the risk group, while 9\% displayed Internet addiction symptoms in Inan (2010) 's study. Balcı and Gülnar 
(2009) determined Internet users at risk as 28.4\%, Günüç (2009) as 29\%, Şahin (2011) as 14\%, İşleyen (2013) as 23\%, Durualp and Çiçekçioğlu (2013) as 66\%, and Yücelten (2016) as 11\%. In the study of Döner (2011), 9\% of the sample showed limited symptoms.

Considering the data on the gender variable, it can be said that male students are at a higher risk of Internet addiction in comparison to female students. There are many studies that support this situation. Scherer (1997) analyzed 531 Internet user students and found that the majority (71\%) of the students identified as Internet addicts were male students. Usta (2016) found that males displayed more Internet addiction behaviors compared to females. Ayaroğlu (2002) reported that males spent more time on Internet surfing and file transfer compared to males, while Gencer (2017) and Döner (2011) stated that male students exhibited Internet addiction behavior more than female students. Similarly, Morahan-Martin and Schumacher (2000), Chou and Hsiao (2000), Bayraktar (2001), Koch and Pratarelli (2004), Aktaş (2005), Yang and Tung (2007), Balta and Horzum (2008), Ögel and Cömert (2009), Günüç (2009), Kelleci et al. (2009), Tsai et al. (2009), Esen (2010), Gürcan (2010), Yıldız (2010), Taçyıldız (2010), Döner (2011), Gencer (2011), Liberatore et al. (2011), Carli et al. (2012), Gökçearslan and Günbatar (2012), Yılmaz (2013), Zorbaz (2013), Türkoğlu (2013), Azher et al. (2014), Waldo (2014), Ceyhan E. (2016), İşsever (2016), and Ünsal (2016) also stated that male students had higher Internet addiction levels than female students in terms of gender variable. These findings support the data obtained in the research in terms of gender variable. However, there are also studies revealing that there was no significant relationship between Internet addiction and gender. Brenner (2000), Batıgün and Kılıç (2011), Kaya (2011), Jelenhick et al. (2012), Hawii (2012), Çalışgan (2013), Andreou and Svoli (2013), Dikme (2014), Dalgalı (2016), and Yücelten (2016) also found that gender had no effect on Internet addiction. In a small number of studies, it was observed that Internet addiction was in favor of female students (Griffiths, 1995; Griffiths, 2000, Beşaltı, 2016). The difference between the gender variable and Internet addiction may be due to the measurement method of Internet addiction level in research or regional and cultural differences (Balta and Horzum, 2008, pp. 187-205). In addition, factors such as gender inequality in the society, the advantage of males in accessing opportunities, and the fact that males go to the Internet and online game rooms more than females can be listed (Taşpınar and Gümüş, 2005, p. 80; Çavuş and Gökdaş, 2006, p. 57). On the other hand, female students may be deprived of technological opportunities (Çavuş and Gökdaş, 2006), their free time can be little due to their responsibilities at home, or their freedom areas may be narrowed through intervention (as cited in Yilmaz, 2013, p.75). Due to the patriarchal family structure of the Turkish society, males can be more easy-going and freer than females. In addition, the emergence of these results in the province of Malatya, where the patriarchal structure has been observed despite immigration it has received in recent years, is a typical situation that represents the country in general.

According to the findings of the school level in the study, high school senior students had a tendency to use the Internet more than primary and secondary school senior students. It was found that primary and secondary school senior students used Internet less than high school senior students. Therefore, their Internet addiction levels were found to be lower. Based on this result, the fact that high school senior students have more individual freedom than primary and secondary school senior students, and that they may have found more space in the family independent of their parents are thought to have increased their Internet addiction. Besides, the fact that the development characteristics of high school senior students in different areas are more complicated than primary and secondary school students indicates that these students may have more intense interest and engagement on the Internet. Accordingly, high school students may have spent more time on the Internet and become more Internet addicted than primary and secondary school students. No study was found in the literature that aimed to find a relationship between Internet addiction and the school level. However, in most of the studies, it was seen that the relationship between Internet addiction and the level of education was investigated. In this regard, while Bayraktar (2001) and Günüç (2009) found a significant difference in Internet addiction levels between secondary school grade levels, Wu and Tsai (2006) found that students' grade levels 
were important in terms of their attitudes towards the Internet. Inan (2010) reached the conclusion that Internet addiction levels of primary and secondary school students differed according to their grade levels. Doğan (2008) found that the Internet addiction status of the students differed significantly according to their grade level. Contrasting findings have also been reached. DiNicola (2004) stated that there was no significant difference between Internet addiction and the year of study levels of university students. Ceyhan (2008) applied the problematic Internet use scale he developed to university students and found that the Internet use levels of the students did not show a significant difference according to their year of study. Kaya (2011) and Şahin (2011) also did not find a significant relationship between students' grade levels and Internet addiction. Looking at the studies conducted, there is a significant difference between the studies conducted on primary and secondary school students and the studies conducted on university students. While studies on primary and secondary school students generally found a significant difference between Internet addiction level and grade level, there was no significant difference in the studies conducted on university students in terms of year of study.

There are a limited number of studies in the literature which aimed to find a relationship between Internet addiction and parents' education level. In most of the studies accessed, the education level of parents was examined. Gencer (2017), Saatçioğlu (2016), İsssever (2016), Dalgalı (2016), Türkoğlu (2013), Zorbaz (2013), Doğan (2013), and Şahin (2011) could not determine a significant relationship between students' Internet addiction and their mother's education level. On the other hand, Gencer (2017), Saatçioğlu (2016), İşsever (2016), Daltalı (2016), Doğrusever (2015), Ayas and Horzum (2013), Doğan A. (2013), Tanrıverdi (2012), and Üneri and Tanı (2011) concluded that there was no significant relationship between the education level of the fathers of students and their Internet addiction behaviors. However, Demetrovics et al. (2008) found that Internet addiction decreased as the education level of family increased, and that as the education level of the individual increased, the tendency to Internet addiction decreased. Batıgün and Kılıç (2011), Koyuncu et al. (2012), Inan (2010) determined that the education levels of the mothers of primary and secondary school students and their Internet addiction status differed positively.

Regarding the parents' occupation, in the study conducted by Günüç (2009), while there was no significant relationship between the parents' occupations and Internet addiction, the addiction levels of individuals whose parents were "teacher-academician-engineer" and "soldier-police" were found to be higher. Tanriverdi (2012) did not detect a significant difference between the Internet addiction levels of secondary school students and their father's occupations. The fact that there was no significant difference between Internet addiction and income levels of families can be attributed to the availability of the Internet for those at different socio-economic levels. This finding coincides with the studies conducted in the literature in terms of the family income level variable. Bakken et al. (2009), Balta and Horzum (2008) and Song (2003) revealed that there was no relationship between Internet addiction and socioeconomic level. Esen (2010), İnan (2010), Gençer (2011), Beşaltı (2016), Ceyhan (2016) and Daltalı (2016) also reached similar findings. There are also studies contrary to the findings obtained in the literature. Y1lmaz (2013) stated that students with a high economic level were more addicted to the Internet than students with a medium economic level, while Şahin (2011) reported that as the family income level of students increased, they would be more prone to Internet addiction. Similarly, Bayraktar (2001), Batıgün and Kılıç (2011), and Sevindik (2011) also found a positive and significant difference between the economic level and Internet addiction. Kayri and Günüç (2016) also concluded that the children of families with high socioeconomic levels were more likely to become Internet addicts.

\section{Conclusion}

As a result of the clustering analysis conducted to examine the Internet addiction levels of primary, secondary, and high school senior students, $15 \%$ of the students were determined to be in the addicted group, $39 \%$ in the addiction risk group, and $46 \%$ in the non-addicted group. Internet addiction levels of male students 
were found to be significantly higher. A significant difference was found between the scores the students obtained on the total Internet addiction scale and the types of schools where they studied. This difference was found in favor of high school students. The mean scores of the high school senior students were higher than the mean scores of the primary and secondary school senior students. Students' parents were determined to be mostly high school graduates. There was no significant relationship between Internet addiction scale mean scores and parents' education level. The mothers of the students were mostly housewives, and their fathers were mostly civil servants. In addition, there was no significant relationship found between the students' parents' educational status and Internet addiction scale mean scores. It was observed that the family income levels of the students were predominantly in the range of 1,501-3,000 TL, and no significant relationship was found between the Internet addiction scale mean scores.

\section{Recommendations}

Considering that $39 \%$ of the students were found to be in the risk group, students should be informed about Internet addiction both in informatics courses and other related courses, and a certain amount of content related to Internet addiction should be incorporated to these courses. Considering the relationship between gender and Internet addiction scale scores, it was observed that male students had higher mean scores than female students. Similar results were obtained in the literature review, and it was observed that males were comfortable in terms of accessing the Internet. In order to lower males' addiction levels, parents need to have more control and follow-up on male students. When it is considered that Internet addiction has an important place like other substance addictions and the developing technological opportunities are taken into consideration, it is necessary to inform families and young people about this situation through various channels (conferences, seminars, etc.). Various studies in collaboration with different institutions and organizations can be carried out for students who are found to exhibit Internet addiction behavior in schools. The "Internet Addiction Polyclinic", which has been opened in Istanbul Bakırköy Mental Diseases Hospital for the diagnosis and treatment of Internet addiction, can also be opened in other provinces and hospitals, and individuals can be provided with help in terms of controlling their Internet use. This study was carried out with primary, secondary and high school senior students studying in Yeşilyurt district of Malatya province, and similar comparative studies can be conducted in other regions with a wider population and sample. 


\section{REFERENCES}

Ağır, A. (2013). Web 2.0 ve Bilişim Teknolojileri Öğretimi. In S. Şahin, Bilgisayar ve Öğgretim Teknolojileri Eğitimi Özel Öğretim Yöntemleri I-II (p. 175). Ankara: Pegem Akademi.

Akgül, M. (2009, Nisan 14). İnternet Yaşamdır. Retrieved Ocak 26, 2016, from Bianet: http://bianet.org/bianet/siyaset/113820-internet-yasamdir

Akınoğlu, O. (2002). Eğitim ve Sosyalleşme Açısından İnternet Kullanımı. Sakarya: Sakarya Üniversitesi Sosyal Bilimler Enstitüsü.

Akpınar, Y. (2005). Bilgisayar Destekli Eğitimde Uygulamalar. Ankara: Anı Yayıncılık.

Aksoy, F. (2016). Ergenlerde İnternet Bağımlılı̆̆ı ile Şema Mekanızmaları ve Başetme Becerileri Arasındaki İlişkinin İncelenmesi. İstanbul: Üsküdar Üniversitesi Sosyal Bilimler Enstitüsü Klinik Psikoloji Ana Bilim Dalı.

Aksu, H., \& İrgil, E. (2003). İnternetin Uludağ Üniversitesi Tıp Fakültesi 5. ve 6. sınıf öğrencilerinin hayatındaki yeri. Uludağg Üniversitesi Tip Fakültesi Dergisi, 29(2), 19-23.

Aksüt, M., \& Batur, Z. (2007). İnternet perspektifinde ergenlerin sosyalleşme ve iletişim kurma süreci.

Aktaş, Y. (2005). 3-18 Yaş Grubu Çocuk ve Gençlerin İnteraktif İletişim Araçlarını Kullanma Alışkanlıklarının Değerlendirilmesi. The Turkish Online Journal of Educational Technology, 59-66.

Alaçam, H. (2012). Denizli Bölgesi Üniversite Öğrencilerinde İnternet Bağımlılı̆̆ııın Görülme Sıklığı ve Yetişkin Dikkat Eksikliği Hiperaktivite Bozukluğu ile İlişkisi . Denizli: Pamukkale Üniversitesi Tıp Fakültesi.

Altın, F. (2006). İnternet Kullanımının Gençlere Etkisi Kastamonu İli Örneği. Ankara: Gazi Üniversitesi Eğitim Bilimleri Enstitüsü.

Altun, A. (2003, Nisan 29). Yurdum İnterneti 10 Yaşında. Retrieved Nisan 1, 2016, from İnternet Arşivi: http://www.internetarsivi.metu.edu.tr/10yil.php

Andreou, E., \& Svoli, H. (2013). The Associatin Betwwen Internet User Characterictics and Dimensions of Internet Addiction among Greek Adolescents. Int J Menth Health Addiction, 139-148.

APA. (1994). Diagnostic and Statistical Manual of Mental Disorders. Washington: American Psychatric Association.

Araptarll, N. (2014). Sanal varoluş. Retrieved 2 14, 2015, from Doktor Sitesi.com: http://www.doktorsitesi.com/makale/sanal-varolus-

AREM. (2008). İnternet ve. Ankara: T.C. İçişleri Bakanlığı Araştırma ve Etütler Merkezi.

Arısoy, Ö. (2009). İnternet Bağımlılığı ve Tedavisi. Psikiyatride Güncel Yaklaşımlar, 55-67.

Armstrong, L., Phillips, J. G., \& Saling, L. L. (2000). Potential determinants of havier internet usage. Int. J. Human-Computer Studies, 537-550.

Arnett, J. J. (1999). Adolescent Storm and Stress. American Psychologist, 317-326.

Asam. (2011, 4 19). Definition of Addiction. Retrieved 2 27, 2015, from ASAM (American Society of Addiction Medicine): http://www.asam.org/for-the-public/definition-of-addiction

Aslanbay, M. (2006). A compulsive consumption: Internet use addictiontendency the case of Turkish high school students. İstanbul: Marmara Üniversitesi Sosyal Bilimler Enstitüsü.

Ata, B. (2015). Bilim ve Teknolojinin Sosyal Değişime Etkisi. In B. Ata, Bilim, Teknoloji ve Sosyal Değgişme (p. 6). Ankara: Pegem Akademi. 
Ayaroğlu, N. S. (2002). The Relationship Between Internet Use and Loneliness of University Students. Ankara: Orta Doğu Teknik Üniversitesi Eğitim Bilimleri Bölümü, Yayımlanmamış Yüksek Lisans Tezi.

Ayas, T., \& Horzum, M. B. (2013). Internet Addiction and Internet Parental Style of Primary School Students. Turkish Psychological Counseling and Guidance Journal, 46-57.

Aydın, M. (2014). Eğitim Yönetimi. Ankara: Gazi Kitabevi.

Aydoğan, F. (2010). İkinci Medya Çağı'inda Gözetim ile Kamusal Alan Paradoksunda İnternet. In A. Filiz, \& A. Ayşen, İkinci Medya Çağında İnternet (pp. 2-3). İstanbul: Alfa Yayınları.

Ayvacı, H. Ş. (2012). Teknolojik Proje Tasarımı. Ankara: Pegem Akademi.

Azher, M., Khan, R. B., Salim, M., Bilal, M., Hussain, A., \& Hseeb, M. (2014). The Relationship between Internet Addiction and Anxiety among students of University of Sargodha. International Journal of Humanities and Social Science, 288-293.

Bağımlılık ve Tedavisi Bilgi Merkezi. (2015). Retrieved 1 10, 2015, from www.bagimlilik.info.tr: http://www.bagimlilik.info.tr/internet_bagimliligi.html

Baker, E. Ö., \& Topçu, Ç. (2013). Siber Zorbalık. In M. Kalkan, \& C. Kaygusuz, İnternet Bağımlılığı Sorunlar ve Çözümleri (p. 51). Ankara: Anı Yayıncılık.

Bakken, I. J., Wenzel, H. G., Götestam, K. G., Johansson, A., \& Ören, A. (2009). Internet addiction among norwegian adults a stratified probability sample study. ScandinavianJournal of Psychology, 50(2), 121-127.

Bal, H. Ç. (2012). Bilgisayar ve Internet Kullanımı. Trabzon: Murathan Yayınevi.

Balcı, Ş., \& Gülnar, B. (2009). Üniversite Öğrencileri Arasında İnternet Bağımlılığı ve İnternet Bağımlılarının Profili. Selçuk İletişim, 5-22.

Balta, Ö. Ç., \& Horzum, M. B. (2008). The factors that affect internet addiction of students in a web based learning environment. Ankara University Journal of Faculty of Educational Sciences, 41(1), 187-205.

Batıgün, A. D., \& Hasta, D. (2010). Internet addiction: an evaluation in terms of loneliness and interpersonal relationship styles. Anatolian Journal of Psychiatry, 213-219.

Batıgün, A. D., \& Kılıç, N. (2011). İnternet bağımlılığı ile kişilik özellikleri, sosyal destek, psikolojik belirtiler ve bazı sosyo-demografik değişkenler arasındaki ilişkiler. Türk Psikoloji Dergisi, 26(67), 1-10.

Bayhan, V. (2011). Lise öğrencilerinde internet kullanma alışkanlığı ve intrernet bağımlılı̆̆ı (Malatya Uygulaması). Akademik Bilişim Konferansı 2011 (pp. 917-924). Malatya: İnönü Üniversitesi.

Bayrak, H. (2018, Şubat 1). Dijilopedi. Retrieved from Dünyada İnternet Kullanımı ve Sosyal Medya İstatistikleri: https://dijilopedi.com/2018-internet-kullanimi-ve-sosyal-medya-istatistikleri/

Bayraktar, F. (2001). İnternet Kullanımının Ergen Gelişimindeki Rolü. İzmir: Ege Üniversitesi Sosyal Bilimler Enstitüsü.

Bayzan, Ş. (2013). İnternetin Bilinçli ve Güvenli Kullanımı. In M. Kalkan, \& C. Kaygusuz, İnternet Bağımlılığı Sorunlar ve Çözümler (p. 273). Ankara: Anı Yayıncılık.

Beard, K. (2005). Internet addiction: a review of current assessment techniques and potential assessment questions. Cyberpsychology and Behavior, 7-14.

Beard, K., \& Wolf, E. (2001). Modification in the Proposed Diagnostic Criteria for Internet Addiction. CyberPsychology \& Behavior, 377-383. 
Belsare, T. J., Gaffney, G. R., \& Black, D. W. (1997). Compulsive computer use. The American Journal Of Psychiatry, 289.

Beşaltı, M. (2016). Ergenlerde İnternet Bă̆ımlılığı ve Kişisel Özelliklerinin Bazı Sosyo-Demoğrafik Özelliklere Göre Incelenmesi. Gaziantep: Gaziantep Üniversitesi Eğitim Bilimleri Enstitüsü Eğitim Bilimleri Ana Bilim Dal1.

Biçen, H., \& Çavuş, N. (2010). The most prefferred social network sites by students. Procedia Social and Behavioral Sciences 2 , 5864-5869.

Bozkur, B. (2013). İlköğretim II. kademe öğrencilerinde internet bağımlılı̆̆ının çeşitli değiş̧kenlere göre incelenmesi. Ankara: Ankara Üniversitesi Eğitim Bilimleri Enstitüsü.

Bölükbaş, K. (2003). Internet Cafeler ve Internet Bağımlllı̆̆ı Üzerine Sosyolojik Bir Araştırma: Diyarbakır Örneği. Diyarbakır: Dicle Üniversitesi Sosyal Bilimler Enstitüsü.

Bradley, B. P. (1990). Behavioural addictions: common features and treatment implications. British Journal of Addiction(85), 1417-1419.

Brenner, V. (2000). Inceleme. Milwaukee, Wisconsin: Wisconsin School of Professional Psychology.

Briggs, A., \& Burke, P. (2002). A Social History of the Media from Gutenberg to the Internet. 307-308.

Buckingham, D. (2007). Schooling the Digital Generation: Popular Culture, New Media and the Future of Education. London: The Institude of Education.

Büyüköztürk, Ş. (2011). Sosyal Bilimler İçin Veri Analizi El Kitabı. Ankara : Pegem Akademi Yayıncılık.

Büyüköztürk, Ş., Çokluk, Ö., \& Köklü, N. (2014). Sosyal Bilimler İçin İstatistik. Ankara: Pegem Akademi.

Camgöz, N. (1998, Ocak). Siberuzay, sanal gerçeklik ve müze. Bilim ve Teknik Dergisi, 72-75.

Campbell, W. G. (2003). Addiction: A Disease of Volition Caused by a Cognitive Impairment. Can J Psychiatry, 48(10), 669-674.

Canbazoğlu, T. (2003). İnternet Teknolojileri İntranet Uygulamaları. İstanbul: Papatya Yayıncllık.

Cansever, B. A. (2010). Ergenlerin Toplumsallaşmasında İnternet Kullanımının Aile ve Okul Bağlamında Yarattı̆̆ı Sorunlar. İzmir: Ege Üniversitesi Sosyal Bilimler Enstitüsü.

Cao, F., \& Su, L. (2007). Internet addiction among Chinese adolescent: Prelavence and psychological features. Child: Care, Health and Developmant, 33(3), 275-281.

Caplan, E. C. (2003). Preference for Online Social Interaction A Theory of Problematic Internet Use and Psychosocial Well-Being. Communication Research, 625-648.

Carli, V., Durkee, T., Kaess, M., Brunner, R., Wasserman, C., Sarchiapone, M., . . W Wasserman, D. (2012). Prevelance of pathological internet use among adolescent in Europa: Demographic and social factors. Society for the Study of Addiction, 2210-2222.

Carnagey, N. L., \& Anderson, C. A. (2005). The Effects of Reward and Punishment in Violent Video Games on Aggressive Affect, Cognition, and Behavior. Psychological Science, 882-889.

Cash, H. (2009, 28 9). Teen Internet Addiction Is a Growing Problem. Retrieved 2 25, 2015, from Current Events: http://eds.b.ebscohost.com/eds/detail/detail?vid=5\&sid=3d2b051f-9289-4588-8ab9d08be8fa23c5\%40sessionmgr111\&hid=108\&bdata=Jmxhbmc9dHImc210ZT11ZHMtbGl2ZQ\%3d\%3d\#db $=\mathrm{a} 9 \mathrm{~h} \& \mathrm{AN}=44918308$ 
Cengizhan, C. (2005). Öğrencilerin bilgisayar ve internet kullanımında yeni bir boyut: "internet bağımlılığı". M. Ü. Atatürk Ĕ̆itim Fakültesi Ĕ̆itim Bilimleri Dergisi(22), 83-98.

Ceyhan, E. (2008). Ergen Ruh Sağlığı Açısından Bir Risk Faktörü: İnternet Bağımlılığı. Çocuk ve Gençlik Ruh Sağlı̆̆ı Dergisi, 15(2), 109-116.

Ceyhan, E. (2016). İnternet Bağımlılı̆̆ının Bağlanma Stilleri ve Duygu Düzenlemeyle İlişkisi. Van: Yüzüncü Yıl Üniversitesi Eğitim Bilimleri Enstitüsü Eğitim Bilimleri Ana Bilim Dalı Psikolojik Danışmanlık ve Rehberlik Bilim Dalı.

Ceyhan, E., Ceyhan, A. A., \& Gürcan, A. (2007). The validity and realiability of the problematic internet usage scale. Educational Sciences: Theory and Practice, 411-416.

Chen, K., Tarn, J. M., \& Han, B. T. (2004). Internet dependency: Its impact on online behavioral patterns in Ecommerce. Humen Systems Management 23, 49-58.

ChildnetInternational. (2006). Internet Addiction. London: Childnet International.

Chou, C., \& Hasiao, M. C. (2000). Internet addiction, usage, gratifications and pleasure experience: "The Taiwan College Students" case. Comput Education, 35(1), 65-80.

Cicioğlu, M. (2014). Öğrencilerin Problemli İnternet Kullanımı ve Siber Zorbalık Davranışlarına İlişkin Görüşleri. Bolu: Abant İzzet Baysal Üniversitesi Eğitim Bilimleri Enstitüsü.

Cüceloğlu, D. (1994). İnsan ve davranışı Psikolojinin Temel Kavramları. İstanbul: Remzi Kitabevi.

Çağlar, İ., \& Kılıç, S. (2012). Genel İletişim. Ankara: Nobel Yayıncılık.

Çalışgan, H. (2013). İlköğretim Öğrencilerinde İnternet Bağımlılığı ve Siber Zorbalık. İstanbul: Yeditepe Üniversitesi Sosyal Bilimler Enstitüsü, Yayımlanmamış Yüksek Lisans Tezi.

Çam, H. H. (2014). Adölesanlarda İnternet Bă̆ımlılığı Prevalansı İle Psikopatolojik Semptomlar ve Obezite Arasındaki İlişkinin İncelenmesi. Sivas: Cumhuriyet Üniversitesi Sağlık Bilimleri Enstitüsü.

Çam, H. H. (2014). Adölesanlarda İnternet Bağımlılı̆̆ı Prevalansı İle Psikopatolojik Semptomlar Ve Obezite Arasındaki İlişkinin İncelenmesi . CUMHURIYET ÜNIVERSITESI SAĞLIK BILIMLERI ENSTITÜSÜ.

Çavuş, H., \& Gökdaş, İ. (2006). Eğitim Fakültesinde Öğrenim Gören Öğrencilerin İnternetten Yararlanma Nedenleri ve Kazanımları. Yüzüncü Yıl Üniversitesi Ĕ̆itim Fakültesi Dergisi, 3(2), 56-78.

Çelebi, A. (1999, Ocak-Şubat). Bilgisayarın ve İnternetin Yarattı̆̆ı Sağlık Sorunları. Retrieved 2 8, 2015, from İstanbul Tabip Odası: http://www.istabip.org.tr/index.php/yayinlar/hekim-forumu/141-99/2050-hekimforumu-ocak-ubat-1999.html

Çetin, E. (2009). Sosyal iletişim ağları ve gençlik: Facebook örneği. Uluslararası Davraz Kongresi. Isparta.

Çetinkaya, M. (2013). İlköğretim Öğrencilerinde İnternet Bă̆ımlılı̆̆ının İncelenmesi. İzmir: Dokuz Eylül Üniversitesi Eğitim Bilimleri Enstitüsü.

Çoban, A. (2016). Bilişim Teknolojileri Sosyal Yapı ve Eğitim. Ankara: Pegem Akademi.

Çoklar, A. N., Odabaşı, H. F., \& Kabakçı, I. (2007). Yeni Dünya: İnternet-ailelerin yeni dünyadaki sorumlulukları nelerdir? 8. Aybastı-Kabataş Kurultayı (pp. 1-9). Eskişehir: Anadolu Üniversitesi Eğitim Fakültesi.

Çokluk, Ö., Şekercioğlu, G., \& Büyüköztürk, Ş. (2014). Sosyal Bilimler İçin Çok Değiş̧kenli İstatistik SPSS ve Lisrel Uygulamaları. Ankara: Pegem Akademi. 
Çolak, M. (2014). Çocuklarda bilgisayar ve internet bağımlılı̆̆ı. Retrieved 2 14, 2015, from doktorsitesi.com: http://www.doktorsitesi.com/makale/cocuklarda-bilgisayar-ve-internet-bagimliligi-

Dalbudak, E., \& Evren, C. (2013). The relationship of internet addiction severity with attention deficit hiperactivity. Comprehensive Psychildary, 497-503.

Dalgalı, F. N. (2016). Lise Öğrencilerinde Yeme Tutumları ve İnternet Bağımlllı̆̆ının Bazı Değişkenlere Göre İncelenmesi. İstanbul: Beykent Üniversitesi Sosyal Bilimler Enstititüsü Psikoloji Ana Bilim Dalı Klinik Psikolojisi Bilim Dalı.

Davis, R. A. (2001). A cognitive-behavioral model of pathological Internet use. Computers in Human Behavior, 187-195.

Demetrovics, Z., Szeredi, B., \& Rozsa, S. (2008). The Three-foctors model of internet addiction: The Development of problematic internet use questionnaire. Behavior Research Methots, 563-574.

Demir, S. (2012). İnternet Teknolojisi. In İ. H. Sugözü, Temel Bilgi Teknolojileri (p. 356). Ankara: Nobel Yayıncilik.

Demirel, Ö. (2006). Öğretimde Planlama ve Değerlendirme-Öğretme Sanatı. Ankara: Pegem A Yayıncllık.

Derin, S. (2013). Lise Öğrencilerinde İnternet Bağımlılı̆̆ı ve Öznel İyi Oluş. Ankara: Hacettepe Üniversitesi Sosyal Bilimler Enstitüsü.

Dikme, E. (2014). Meslek Lisesi Öğrencilerinin İnternet Bağımlılıklarının Çeşitli Değişkenler Bağlamında İncelenmesi. İstanbul: Yeditepe Üniversitesi Sosyal Bilimler Enstitüsü.

Dikmen, C. H., \& Demirer, V. (2016). İnternet. In S. Şahin, Eğitimde Bilişim Teknolojileri I-II (p. 151). Ankara: Pegem Akademi.

Dinç, M. (2010). İnternet Bağımlılı̆̆ı. İstanbul: Ferfir Eğitim ve Yayıncılık.

Dinç, M. (2012). Türkiye Bă̆ımlılıkla Mücadele Ĕ̆itim Programı. (A. Durmuş, \& H. I. Durmuş, Eds.) İstanbul: Türkiye Yeşilay Cemiyeti.

DiNicola, M. D. (2004). Pathological internet use among college students: The prelevance of pathological internet use and its correlates. Athens: A Dissertation Presented to The Faculty of The College of Education Ohio University.

Doğan, A. (2013). İnternet Bağımlılığı Yaygınlı̆̆ı İzmir: Dokuz Eylül Üniversitesi Eğitim Bilimleri Enstitüsü, Yayımlanmamaış Yüksek Lisans Tezi.

Doğan, H., Işıklar, A., \& Eroğlu, S. E. (2008). Ergenlerin Problemli İnternet Kullanımının Bazı Değişkenler Açısından İncelenmesi. KKEFD, 106-124.

Doğrusever, C. (2015). Ön Ergenlerin internet bağımlılı̆ııın yalnızlı, sosyal beceriler ve bazı sosyo-demografik d̆̆iş̧kenler açısından incelenmesi. Adana: Çukurova Üniversitesi Sosyal Bilimler Enstitüsü.

Doruk, D. (2007). Öğrenme İsteksizliğinin İnternet Kullanımıyla İlişkilendirilmesi. İstanbul: Beykent Üniversitesi Sosyal Bilimler Enstitüsü.

Döner, C. (2011). İlköğretim Öğrencilerinde İnternet Bağımlılığının Farklı Değiş̧kenlere Göre İncelenmesi. Ankara: Ankara Üniversitesi Eğitim Bilimleri Enstitüsü.

Durualp, E., \& Çiçekçioğlu, P. (2013). Yetiştirme Yurdunda Kalan Ergenlerin Yalnızlık Düzeylerinin İnternet Bağımlılığı ve Çeşitli Değişkenler Açısından İncelenmesi. Dokuz Eylül Üniversitesi Sosyal Bilimler Enstitüsü Dergisi, 29-46. 
Duymaz, T. (2013). Arama Motoru Nedir - Nasıl Çalı̧ır? Retrieved Nisan 1, 2016, from semsector: http://semsector.com/arama-motoru-nedir-nasil-calisir/

Eftekin, P. (2015). Ergenlik Dönemindeki Öğrencilerin İnternet Bağımlılığı ve Anne Baba Tutumları Arasındaki İlişkinin İncelenmesi. Kayseri: Erciyes Üniversitesi Eğitim Bilimleri Enstitüsü.

Egger, O., \& Rauterberg, M. (1996). Internet Behaviour and Addiction. Zurich: Work and Organisational Psychology Unit Swiss Federal Institute of Technology.

Einjden, R. J., Meerkerk, G.-J., Vermulst, A. A., Spijkerman, R., \& Engels, R. C. (2008). Online communication, compulsive internet use, and psychosocial well-being among adolescent: A longitudinal study. Developmantal Psychology, 44(3), 655-665.

Ekici, A. (2009). Aziz Antonius'un Baştan Çıkarılması: Bir Kötü Alışkanlık Olarak İnternet.

Elizabeth, H., \& Tee, M. Y. (2007). Excessive internet use: The role of personality, linoliness and social support networks in internet addiction. Australian Journal of Emerging Technologies and Society, 5(1), 34-47.

Ergin, A. (2014). Eğitimde Etkili İletişim. Ankara: Anı Yayıncılık.

Eroğlu, A. (2014). İnternet Bağımlılı̆̆ı İle İlişkili Değişkenlerin İncelenmesi. İstanbul: Haliç Üniversitesi Sosyal Bilimler Enstitüsü.

Ersoy, H. (2013). Eğitimde Bilgisaray Uygulamaları. In E. Cabı, Öğretim Teknolojileri ve Materyal Tasarımı (pp. 128-129). Ankara: Pegem Akademi.

Esen, E. (2010). Ergenlerde İnternet Bağımlılı̆̆ını Yordayan Psiko-Sosyal Değişkenlerin İncelenmesi. İzmir: Dokuz Eylül Üniversitesi Eğitim Bilimleri Enstitüsü.

Eskin, M. (2001). Ergenlikte yalnızlık, başetme yöntemleri ve yanlızlığın intihat davranışı ile ilişkisi. Kilinik Psikiyatri, 5-11.

Flores, P. J. (2004). Addiction as an Attachment Disorder. Northvhale/New Jersey: Jason Aronson Press;.

Gates, B. (1999). Önümüzdeki Yol. (E. Davutoğlu, \& A. Erdal, Trans.) Ankara: Arkadaş Yayınları.

Gencer, H. (2017). Ortaokul Öğrencilerinde İnternet Bağımlılı̆̆ı ve Siber Zorbalık Davranışları ile İlişkili Değişkenlerin İncelenmesi. Sivas: Cumhuriyet Üniversitesi Eğitim Bilimleri Enstitüsü Eğitim Bilimleri Ana Bilim Dalı.

Gençer, S. L. (2011). Ortaöğretim Öğretmen Adaylarmın İnternet Bağımlılık Durumlarının İnternet Kullanım Profilleri ve Demografik Değişkenlere Göre İncelenmesi. Isparta: Süleyman Demirel Üniversitesi Fen Bilimleri Enstitüsü, Yayımlanmamış Yüksek Lisans Tezi.

Goldberg, I. (1996). Internet Addiction Support Group. The Psychology of Cyberspace.

Goldberg, I. (1999). Goldberg's Message. Retrieved Nisan 2, 2016, from Cognitive, linguistic and psychological sciences: http://www.brown.edu/Departments/CLPS/

Gökçearslan, Ş., \& Günbatar, M. S. (2012). Ortaöğretim Öğrencilerinde İnternet Bağımlılı̆̆ı. Eğitim Teknolojisi Kuram ve Uygulama, 2(2), 10-24.

Göker, G., Demir, M., \& Doğan, A. (2010). Ağ toplumunda sosyalleşme ve paylaşım: Facebook üzerine ampirik bir araştırma. E-Journal of New World Sciences Academy Humanities, 5(2), 246-250.

Griffiths, M. (1995). Technological addictions. Clinical Psychology Forum, 14-19.

Griffiths, M. (1999). İnternet Addiction. The Psychologist, 12(5), 246-250. 
Griffiths, M. (2000). Does Internet and Computer Addiction Exist? Some Case Study Evidence. CyberPsychology $\mathcal{E}$ Behaviour,, 211-218.

Griffiths, M. (2009). Online computer gaming: Advice for parents and teachers. Education and Health, 3-6.

Griffiths, M. D. (1999). Internet addiction: Fact or fiction? The Psychologist: Bulletin of the British Psychological Society, 246-250.

Gross, E. F. (2004). Adolescent Internet use: What we expect, what teens report. Applied Developmental Psychology, 633-649.

Gülbahar, Y. (2012). e-öğrenme. Ankara: Pegem Akademi Yayınları.

Güneri, Ö. Ş., \& Tanıdır, C. (2011). Bir Grup Lise Öğerncisinde İnternet Bağımlılığı Değerlendirilmesi: Kesitsel Bir Çalışma. Psikiyatri ve Nörobiyoloji Bilimleri Dergisi.

Günüç, S. (2009). Internet bağgmlılığı ölçeğinin geliştirilmesi ve bazı demografik değişkenler ile internet bağımlılı̆̆ı arasındaki ilişkilerin incelenmesi. Van: Yüzüncü Yıl Üniversitesi Sosyal Bilimler Enstitüsü.

Günüç, S. (2009). İnternet Bağımlılık Ölçeğinin Geliştirilmesi Ve Bazı Demografik Değişkenler İle İnternet Bağımlılı̆̆ı Arasındaki IIlişkilerin İncelenmesi. Van: Yüzüncü Yıl Üniversitesi Sosyal Bilimler Enstitüsü.

Günüç, S., \& Kayri, M. (2009). The Adapdation of Internet Addiction Scale into Turkish: The Study of Validitiy and Reliability. Ankara University Journal of Faculty of Educational Sciences, 157-175.

Gürcan, N. (2010). Ergenlerin Problemli İnternet Kullanımları ile Uyumları Arasındaki İlişkinin İncelenmesi. Konya: Selçuk Üniversitesi Eğitim Bilimleri Enstitüsü, Yayımlanmamış Yüksek Lisans Tezi.

Gürüz, D., \& Eğinli, A. T. (2016). İletişim Becerileri Anlamak-Anlatmak-Anlaşmak. Ankara: Nobel Yayıncılık.

Güven, B. (2016). İletişim Kavramı ve İletişim Sürecinin Temel Öğeleri. In B. Güven, Etkili İletişim (pp. 2-3). Ankara: Pegem Akademi.

Güvenir, H. A. (2005, Aralık). İntenetin Tarihi ve Türkiye. Dergi Bilkent(4), 8-12.

Gwinnell, E., \& Adamec, C. (2006). The Encyclopedia Addictions and Addictive Behaviors. Newyork: Facts on File Librarary of Health and Living.

Hair, J. F., Black, W. C., Babin, B., Anderson, R. E., \& Tatham, R. L. (2006). Multivariate data analysis (6th eddition). Upper Saddle River, NJ: Prentice-Hall.

Hawii, N. S. (2012). Internet Addiction among Adolescents in Lebanon. Computers in Human Behavior, 10441053.

Henderson, E. C. (2000). Understanding Addiction. University Press of Missisipi.

İçel, K. (2015). Kitle İletişim Hukuku. İstanbul: Beta.

İnan, A. (2010). İlköğretim II. kademe ve ortaöğretim öğrencilerinde internet bağımlılı̆̆ı. Erzurum: Atatürk Üniversitesi Sosyal Bilimler Enstitüsü.

Internet Society. (2016). Retrieved 03 10, 2016, from http://www.internetsociety.org/history/brief.shtml.

Internet World Status. (2017, Nisan 30). Retrieved from www.internetworldstatus.com

Işık, U. (2007). Medya bağımlılığı teorisi doğrultusunda internet kullanımının etkileri ve internet bağımlılığı. Konya: Selçuk Üniversitesi Sosyal Bilimler Enstitüsü.

İşleyen, F. (2013). Lise öğrencilerinin internet bağımlılı̆̆ düzeylerinin kişisel ve ailesel faktörlerle ilişkisinin incelenmesi. İzmir: Ege Üniversitesi Sosyal Bilimler Enstitüsü. 
İşsever, N. K. (2016). İnternet Bă̆ımlılığının Üniversite Öğrencilerinde Yaygınlı̆̆ının İncelenmesi. İstanbul: Üsküdar Üniversitesi Sosyal Bilimler Enstitüsü Klinik Psikoloji Ana Bilim Dalı.

Ivory, J. D. (2012). VIRTUAL LIVES A Reference Handbook. Santa Barbara, California: ABC-CLIO, LLC Contemporary World Issues.

Jang, K. S., Hwang, S. Y., \& Choi, J. Y. (2008). Internet Addiction and Psychiatric Symptoms among Korean Adolescents. The Journal of School Health, 78(3).

Janoschka, A. (2004). Web Advertising. Philadelphia: John Benjamins Publishing Company.

Jelenhick, L. A., Becker, T., \& Moreno, M. A. (2012). Assessing the Psychometric Properties of the Internet Addiction Test (IAT) in US College Student. Retrieved Nisan 2, 2016, from Deepdyve: https://www.deepdyve.com/lp/elsevier/assessing-the-psychometric-properties-of-the-internetaddiction-test-nMrpuBM1mB

Johansson, A., \& Götestam, G. K. (2004). Internet addiction: Characteristics of a questoinnaire an prevalence in Norwegian Youth (12-18 years). Scandinavian Journal of Psycholog, 45, 223-229.

Jucker, A. H. (2003). Mass media communication at the beginning of the twenty-first century: Dimensions of change. Journal of Historical Pragmatics, 4(1), 129-148.

Kabaca, T. (2012). Bilgisayar Destekli Öğretim ile İlgili Kavramlar. In A. Benzer, \& H. Aksaya, Bilgisayar Okuryazarlı̆̆ı I-II (p. 322). Ankara: Pegem Akademi.

Kalaycı, Ş. (2006). In SPSS Uygulamahı Çok Değişkenli İstatistik Teknikleri. Ankara: Asil Yayıncılık.

Kalaycı, Ş. (2006). SPSS Uygulamalı Çok Değişkenli İstatistik Teknikleri. Ankara: Asil Yayıncllık.

Kalkan, M., \& Kaygusuz, C. (2013). Önsöz. In İnternet Bağımlılı̆̆ı Sorunlar ve Çözümler (pp. 3-4). Ankara: Anı Yayıncilik.

Kalkan, M., \& Kaygusuz, C. (2013b). İnternet Bă̆ımlılığı Sorunlar ve Çözümler. Ankara: Anı Yayıncılık.

Kaltiala-Heino, R., Lintonen, T., \& Rimpela, A. (2004). Internetaddiction? Potentially problematic use of the internet in a population of 12-18 year-old adolescents. Addiction Research and Theory, 12(1), 89-96.

Karabulut, S. (2013). Arama Motoru Nedir ve Çeşitleri. Retrieved Nisan 1, 2016, from blogspot: http://karabulut38.blogspot.com.tr/2013/10/arama-motoru-nedir-ve-cesitleri.html

Karaca, M. (2007). Sosyolojik bir olgu olarak internet gençliği: Elazı̆̆ örneği, Yayımlanmamaış Doktora Tezi. Elazığ: Firat Üniversitesi Sosyal Bilimler Enstitüsü Sosyoloji Anabilim Dalı.

Karahan, M. (2001). İnternet Ĕ̆itimine Giriş. Malatya: Kubbe Yayıncılık.

Karasar, N. (2011). Bilimsel Araştırma Yöntemi. İstanbul: Nobel Yayın Dağıtım.

Karasar, N. (2011). Bilimsel araştırma yöntemi : kavramlar, ilkeler, teknikler. Ankara: Nobel.

Kaşıkcı, D. N. (2014). Çocukların, Ebeveynlerin Ve Öğretmenlerin; Çocuklar İçin İnternet Kullanımı, İnternetin Riskleri ve Güvenliği Hakkında Görüşleri ve Deneyimleri. Ankara: Orta Doğu Teknik Üniversitesi Fen Bilimleri Enstitüsü.

Kaya, A. (2010). Kişilerarası ilişkiler ve etkili iletişim. Ankara: Pegem A Yayıncılık.

Kaya, A. (2011). Öğretmen adaylarının sosyal ă̆ sitelerini kullanım durumları ve internet bağımlılı̆̆ı düzeyleri. İzmir: Ege Üniversitesi Fen Bilimleri Enstitüsü.

Kaypakoğlu, S. (2008). Kişilerarası İletişim Cinsiyet Farklılıkları Güç ve Çatışma . İstanbul: Derin Yayınları. 
Kayri, M., \& Günüç, S. (2009). İnternet bağımlılık ölçeğinin türkçeye uyarlanması: Geçerlik ve güvenirlik çalışması. Ankara Ünversitesi Ĕ̆gitim Bilimleri Fakültesi Dergisi, 42(1), 157-175.

Kayri, M., \& Günüç, S. (2009). İnternet bağımlılık ölçeğinin Türkçe'ye uyarlanması: Geçerlik ve güvenirlik çalışması. Ankara Üniversitesi Ĕ̆itim Bilimleri Fakülte Dergisi, 42(1), 157-165.

Kayri, M., \& Günüç, S. (2016). Yüksek ve Düşük Sosyoekonomik Koşullara Sahip Öğrencilerin İnternet Bağımlılı̆̆ı Açısından Karşılaştırmalı Olarak İncelenmesi. Addicta, 165-183.

Kazdal, Y. M. (2014). Internet Bă̆ımlılı̆̆ı. Retrieved 2 14, 2015, from doktorsitesi.com: http://www.doktorsitesi.com/makale/internet-bagimliligi-

Kelleci, M., Güler, N., Sezer, H., \& Gölbaşı, Z. (2009). Lise Öğrencilerinde İnternet Kullanma Süresinin Cinsiyet ve Psikiyatrik Belirtiler ile İlişkisi. TAF Preventive Medicine Bulletin, 8(3), 223-230.

Keser, H. (2005). İnsan-Bilgisayar Etkileşimi ve Sağhı̆̆a Etkisi. Ankara: Nobel Yayıncılık.

Ko, C.-H. (2009). Psychiatric symptoms may predict internet addiction in teens. Brown University Child and Adolescent Behavior Letter, 3-4.

Ko, C.-H., Yen, J.-Y., Chen, C.-C., Chen, S.-H., \& Yen, C.-F. (2005). Proposed diagnostic criteria of internet addiction for adolescent. J Nerv Ment Dis, 193, 728-733.

Koch, W. H., \& Pratarelli, M. E. (2004). Effects of intro/extraversiyon and sex on social internet use. North American Journal of Psychology, 6(3), 371-382.

Kraut, R., Petterson, M., Lundmark, V., Kiesler, S., Mukopadhyay, T., \& Scherlis, W. (1998). A Social Technology That Reduces Social Involvement and Psychological Well-Being? American Psychologist, 1017-1031.

Kubey, R. W., Lavin, M. J., \& Barrows, J. R. (2001). Internet use and collegiate academic performance decrements: Early findings. International Communication Association, 366-382.

Kurtaran, T. G. (2008). İnternet Bağımlılı̆̆ın Yordayan Değı̧şkenlerin İncelenmesi. Mersin: Mersin Üniversitesi Sosyal Bilimler Enstitüsü.

Larkin, M., Wood, R. T., \& Griffiths, M. D. (2006). Towards Addiction as Relationship. Addiction Research and Theory, 14(3), 207-215.

Leiner, B. M., Cerf, V. G., Clark, D. D., Kleinrock, L., Lynch, D. C., Postel, J., ... Wolff, S. (2016). Internet Society. Retrieved Mart 31，2016, from http://www.internetsociety.org/internet/what-internet/historyinternet/brief-history-internet\#Timeline

Leung, L. (2004). Net- Generation attributes and seductive properties of the internet as predictors of online activites and internet addiction. CyberPsychology, 7(3), 333-348.

Leung, L., \& Lee, P. S. (2011). The influences of information literacy internet addiction and parenting styles on internet risks. New Media and Society, 1-21.

Li, S. M., \& Chung, T. M. (2006). Internet Function and Internet Addictive Behavior. Computers in Human Behavior, 1067-1071.

Liberatore, K. A., Rosario, K., Marti, L. C.-D., \& Martinez, K. (2011). Prevalence of Internet Addiction in Latino Adolescent with Psychiatric Diagnosis. Cyberpsychology, 1-4.

Marks, I. (1990). Behavioural (non-chemical) addictions. British Journal of Addiction, 1389-1394.

Marks, I. (1990). Behavioural (non-chemical) addictions. British Journal of Addiction, 1389-1394. 
MEB. (2010). Madde Bağımlılı̆̆ı İle Mücadele Öğretmen El Kitabı. Ankara: Milli Eğitim Bkanlığı.

Melek, K. (2015). Sosyal İlgi. In B. E. Tekinalp, \& Ş. I. Terzi, Eğitimde Pozitif Psikoloji Uygulamaları (pp. 290-293). Ankara: Pegem Akademi.

Moody, E. J. (2001). Internet Use and Its Relationship to Loneliness. Cyber Psychology \& Behavior, 393-401.

Mora, N. (2011). Medya Çalışmaları Medya Pedagojisi ve Küresel İletişim. Ankara: Nobel Yayıncılık.

Morahan-Martin, J., \& Schumacher, P. (2000). Incidence and correlates of pathological internet use among college students. Computers in Human Behavior(16), 13-29.

Morrison, J. (2016). DSM-5'i Kolaylaştıran Klinisyenler İçin Tanı Rehberi. Ankara: Nobel Yayıncllık.

Muslu, G. K., \& Bolışık, B. (2009). Çocuk ve Gençlerde İnternet Kullanımı. TAF Preventive Medicine Bulletin, 445-850.

Net Addiction. (2015). Retrieved 1 11, 2015, from What is Internet Addiction Disorder: http://netaddiction.com/faqs/

Netherland, J. (2012). Critical Perspectives on Addiction. HowardHouse, WagonLane, Bingley BD16 1WA, UK: Emerald Group Publishing Limited.

Newhagen, J. E., \& Rafaeli, S. (1996). Why communication researchers should study the internet: A dialouge. Journal of Communication, 4-16.

Nichols, N. A., \& Nicki, R. (2004). Development of a Psychometrically Sound Internet Addiction Scale: A Preliminary Step. Psychology of Addictive Behaviors, 381-384.

Niemz, K., Griffiths, M., \& Banyard, P. (2005). Prevalence of pathological internet use among university students and correlations with self esteem, the General Health Questionnaire (GHQ), and disinhibition. CyberPsychology and Bahavior, 8(6), 562-570.

Odabaşı, H. F., Kabakçı, I., \& Çoklar, A. N. (2007). İnternet, çocuk ve aile. Ankara: Nobal Yayın Dağıtım.

Odabaşıŏlu, G., Öztürk, Ö., Genç, Y., \& Pektaş, Ö. (2007). On Olguluk Bir Seri Ġle Ġnternet Bağımlılı̆̆ı Klinik Görünümleri. Bă̆ımlılık Dergisi, 46-51.

Orzack, H. (1999). Computer Addiction: Is It Real or Virtual? Harvard Mental Health Letter.

Ögel, K. (2012). Neden İnternet ve Bilgisayar Bağımlıı̆ğı. Retrieved 2 6, 2015, from www.internetbagimliligi.info: http://www.internetbagimliligi.info/neden_internet_bagimliligi.asp

Ögel, K. (2014). İnternet Bağımlılı̆̆ı İnternetin psikolojisini anlamak ve băğımlılıkla başa çıkmak. İstanbul: Türkiye İş Bankası Kültür Yayınları.

Ögel, K., \& Cömert, I. T. (2009). İnternet ve Bilgisayar Bağımlılığının Yaygınlığı ve Farklı Etkenlerle İlişkisi. Türkiye Klinikleri J Foren Med, 6(1), 9-16.

Özcan, N. K., \& Buzlu, S. (2005). Problemli internet kullanımını belirlemede yardımcı bir araç: "internette bilişsel durum ölçeği"nin üniversit öğrencilerinde geçerlik ve güvenirliği. Bağımlılık Dergisi, 6(1), 19-26.

Özçağlayan, M. (1998). Yeni İletişim Teknolojileri ve Değişim. İstanbul: Alfa Yayınları.

Özdamar, K. (2010). Paket programlar ile istatistiksel veri analizi. Ankara: Nisan Kitabevi.

Özdemir, G. (2016). Ondokuz Mayıs Üniversitesi Tıp Fakültesi Öğrencilerinde Internet Bağımlılı̆̆ı ve Depresyon Arasındaki İlişkinin Değerlendirilmesi. Ankara: Ankara Üniversitesi Tıp Fakültesi. 
Özdemir, S. (2005). WEB ortamında bireysel ve işbirlikli problem temelli öğrenmenin eleştirel düşünme becerisi, akademik başarı ve internet kullanımına yönelik tutuma etkileri. Ankara: Gazi Üniversitesi Eğitim Bilimleri Enstitüsü.

Özer, Ş. (2013). Problemli İnternet Kullanımının Benlik Saygısı ve Öznel İyi Oluş ile Açıklanabilirliği. Trabzon: Karadeniz Teknik Üniversitesi Eğitim Bilimleri Enstitüsü.

Özhan, G., Bay, Y., İşgüzar, M., \& Kardeş, G. (2010). Madde Bağımlılığı ile Mücadele Öğretmen El Kitabı. Ankara: Milli Eğitim Bakanlığı Özel Eğitim Rehberlik ve Danışma Hizmetleri Genel Müdürlüğü.

Öztürk, E., \& Özmen, S. K. (2011). Öğretmen adaylarının problemli internet kullanım davranışlarının kişilik tipi, utangaçlık ve demografik değişkenlere göre incelenmesi. Kuram ve Uygulamada Ĕ̆itim Bilimleri, 11(4), 1785-1808.

Öztürk, F. Ö., Ekinci, M., Öztürk, Ö., \& Canan, F. (2013). The Relationship of Affective Temperament and Emotional-Behavioral Difficulties to Internet Addiction in Turkish Teenagers. Hindawi Publishing Corporation ISRN Psychiatry, 1-6.

Padwa, H., \& Cunningham, J. (2010). Addiction A Reference Encyclopedia. Santa Barbara,California: BCCLIO,LLC.

Paska, L. M., \& Yan, Z. (2011). Internet Addiction in Adolescence and Emerging Adulthood: A Comparison between the United States and China. In H. O. Price (Ed.), Internet Addiction (pp. 1-28). New York: Nova Science Publishers.

Peker, A. (2013). İnsani Değerler Yönelimli Psiko-Eğitim Programının Problemli İnternet Kullanımı ve Siber Zorbalık Üzerindeki Etkisi. Sakarya: Sakarya Üniversitesi Eğitim Bilimleri Enstitüsü.

Pınar, Z. (2014). Internet bağımlılı̆̆ı. Retrieved 2 14, 2015, from doktorsitesi.com: http://www.doktorsitesi.com/makale/internet-bagimliligi--101985

Pontes, H. M., Griffiths, M. D., \& Patrao, I. M. (2014). Internet Addiction and Loneliness Among Children and Adolescents in the Education Setting: An Empirical Pilot Study. Revista de Psicologia, Ciències de l'Educació i de l'Esport, 91-98.

Pratarelli, M. E., Browne, L., \& Johnson, K. (1999). The bits and bytes of computer/Internet addiction: A factor analytic approach. Behavior Research Methods. Instruments, \& Computers, 31(2), 305-314.

Price, H. (2011). Psychology of Emotions, Motivations and Actions Internet Addiction. New York: Nova Science Publishers, Inc.

Ravid, R. (1994). Practical Statistics for Educators. New York: University Press of America Inc.

Saatçi, A. (2005, Kasım 9). Bilgi teknolojisindeki gelişme ve yarattığı bilgi devriminin ulaştığı boyutlar. Gelişen Bilgi Teknolojisi ile Güvenlik Politikası ve Stratejileri Arasında Etkleşim ve Yönlendirme Sempozyumu, (pp. 122152). İstanbul.

Saatçioğlu, H. (2016). İnternet Bağımlılı̆̆ı Tanısı Alan Ergenlerin Sosyal Bilişsel Becerilerinin Değerlendirilmesi. İzmir: Ege Üniversitesi Tıp Fakültesi Çocuk ve Ergen Ruh Sağlığı ve Hastalıkları Ana Bilim Dalı.

Sanders, C. E., Alan, T. M., Diego, M., \& Kaplan, M. (2000). Depresyon ve Ergenlerde Sosyal İzolasyon İnternet Kullanımı İlişkisi. Questia Gale, 35(138), 237-242.

Selimoğlu, E. (2006, 06 10). İletişim Becerileri ve Yönetici Asistanlı̆̆ında İletişimin Önemi. Retrieved from İnsan Kaynakları: www.insankaynaklari.com 
Sevindik, F. (2011). Fırat Üniversitesi Öğrencilerinde Problemli İnternet Kullanımı ve Sağlıklı Yaşam Biçimi Davranışlarının Belirlenmesi. Malatya: İnönü Üniversitesi Sağlık Bilimleri Enstitüsü.

Shaffer, H. (1999). On the Nature and Meaning of Addiction. National Forum, 79(4), 9-14.

Shaffer, H. J., Hall, M. N., \& Bilt, J. V. (2000). “Computer Addiction”: A Critical Consideration. Amencan journal of Orthopsychiatry, 162-168.

Shapira, N. A., Goldsmith, T. D., Keck, P. E., Khosla, U. M., \& McElroy, S. L. (2000). Psychiatric features of individuals with problematic internet use. Journal of Affective Disorders(57), 267-272.

Shaw, M., \& Black, D. W. (2008). Internet Addiction Definition, Assessment, Epidemiology and Clinical Management. CNS Drug, 353-365.

Simkova, B., \& Cincera, J. (2004). Internet addiction disorder and chatting in the Czech Republic. CyberPschology and Behavior, 7(5), 536-539.

Sırakaya, M. (2011). Öğretmen Adaylarının Problemli İnternet Kullanımı Ve İnternet Öz-Yeterlik Düzeylerinin İncelenmesi. Ankara: Hacettepe Üniversitesi Fen Bilimleri Enstitüsü.

Smahel, D., Helsper, E., Green, L., Kalmus, V., Blinka, L., \& Olafsson, K. (2012). Excessive Internet Use among European Children. Retrieved 211, 2016, from www.eukidsonline.net

Small, G., \& Vorgan, G. (2009). E-Beyin:Modern Beynin Evrimi. (M. Duygun, Trans.) İstanbul: Omega Yayınları.

Sorubak. (2010, Şubat 27). Internetin hayatımızdaki yeri ve önemi. Retrieved Mart 12, 2016, from http://www.sorubak.com/blog/internetin-hayatimizdaki-yeri-ve-onemi.html

Soydan, Z. M. (2015). Üniversite Öğrencilerinin İnternet Bă̆ımlılı̆̆ ile Depresyon ve Yaşam Doyumu Arasındaki İlişki. İstanbul: Haliç Üniversitesi Sosyal Bilimler Enstitüsü.

Sözer, Y. (2014). İnternet çağında sanal yalnızlı. Retrieved 2 14, 2015, from doktorsitesi.com: http://www.doktorsitesi.com/makale/internet-caginda-sanal-yalnizlik

Stewart, W. (2000, Ocak 7). Internet History. Retrieved Nisan 1, 2016, from living internet: http://www.livinginternet.com/i/ii_summary.htm

Suler, J. (1999). Healthy and Pathological Internet Use. CyberPsychology and Behavior, 385-394.

Supçin, E. (2012, Kasım 4). FTP Nedir? Ne işe yarar? FTP komutları nelerdir? Retrieved Nisan 1, 2016, from eminesupçin: http://www.emresupcin.com/ftp-nedir-ne-ise-yarar-ftp-komutlari-nelerdir/

Şahin, M. (2007). Madde Bağımlılı̆̆ı Konusunda Türkiye'de Yapılmış Olan Lisansüstü Tezler Üzerine Bir Değerlendirme. Ankara: Ankara Üniversitesi Sağlık Bilimleri Enstitüsü.

Şahin, M. (2011). İlköğretim Okulu Öğrencilerindeki İnternet Bă̆ımlılı̆̆ı. İstanbul: Yeditepe Üniversitesi Sosyal Bilimler Enstitüsü.

Tabachnick, B. G., \& Fidell, L. S. (2015). In Using Multivarite Statistics (p. 81). Boston: Pearson.

Taçyıldız, Ö. (2010). Lise Öğrencilerinin İnternet Bă̆ımlılı̆̆ı Düzeylerinin Bazı Değişkenlere Göre Yordanması. İzmir: Ege Üniversitesi Sosyal Bilimler Enstitüsü.

Tahiroglu, A. Y., Çelik, G. G., Uzel, M., Ozcan, N., \& Avci, A. (2008). İnternet Use Among Turkish Adolescents. CyberPsychology and Behavior, 11(5), 537-543.

Tahiroğlu, A. Y., Çelik, G. G., Uzel, M., Özcan, N., \& Avcı, A. (2008). Internet use among Turkish adolescents. CyberPsychology and Behavior, 11(5), 537-543. 
Tanrıverdi, S. (2012). Ortaöğretim Öğrencilerinde İnternet Bağımlılı̆̆ı ile Algılanan Sosyal Destek Arasındaki Illişkinin İncelenmesi. Van: Yüzüncü Yıl Üniversitesi Eğitim Bilimleri Enstitüsü, Yayımlanmamış Yüksek Lisans Tezi.

Tanyeri, T. (2009, Haziran 6). Hiper Metin ve Hiper Ortam. Retrieved Şubat 2, 2016, from blogspot: http://mustafatoy.blogspot.com.tr/2009/06/hiper-metin-ve-hiper-ortam.html

Tarcan, A. (2005). Dünden Bugüne İnternet Üzerine Felsefi Yaklaşımlar. In A. Tarcan, İnternet ve Toplum (p. 3). Ankara: Anı Yayıncilık.

Tarhan, N., \& Nurmedov, S. (2013). Bağımlılık. İstanbul: Timaş Yayınları.

Taşpınar, M., \& Gümüş, Ç. (2005). Ülkemizde İnternet Kafelerin Ortam ve Kullanıcı Profilleri. Elektronik Sosyal Bilimler Dergisi, 80-93.

TBMM. (2012). Bilgi toplumu olma yolunda bilişim sektöründeki gelişmeler ile İnternet kullanımının başta çocuklar, gençler aile yapısı üzerinde olmak üzere sosyal etkilerinin araştırılması amacıyla kurulan meclis araştırması komisyonu raporu. Ankara: TBMM.

Tekinarslan, E. (2012). Eğitimde İnternet Kullanımı. In Ö. Demirel, \& E. Altun, Öğretim Teknolojileri ve Materyal Tasarımı (p. 169). Ankara: Pegem Akademi.

Teleperformance. (2015). Retrieved Aralık 3, 2015, from http://www.teleperformance.com.tr/2015-guncelsosyal-medya-istatistikleri-Blog-72

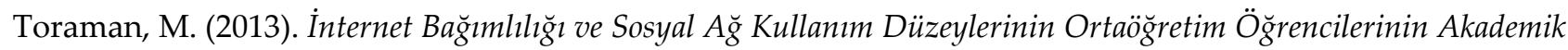
Başarıları ile İlişkisinin İncelenmesi. Elazı̆̆g: Fırat Üniversitesi Eğitim Bilimleri Enstitüsü.

Tsai, H. F., Cheng, S. H., Yeh, T. L., Shih, C.-C., Chen, K. C., Yang, Y. C., \& Yang, Y. K. (2009). Assessing the psychometric properties of the internet addiction test (IAT) in USA. Retrieved 1 23, 2016, from Psychiatry Research: https://www.deepdyve.com/lp/elsevier/the-risk-factors-of-internet-addiction-a-survey-ofuniversity-freshmen-AH73PedpS3

TÜİK. (2015, Ağustos 18). Hanehalkı Bilişim Teknolojileri Kullanım Araştırması, 2015. Retrieved Şubat 22, 2016, from TÜiK: http://www.tuik.gov.tr/PreHaberBultenleri.do?id=18660

TÜiK. (2016, Ağustos 18). Hanehalkı Bilişim Teknolojileri Kullanım Araştırması, 2016. Retrieved from Türkiye İstatistik Kurumu: http://www.tuik.gov.tr/PreHaberBultenleri.do?id=21779

Türkçebilgi. (2004). E-posta Nedir? Retrieved Şubat 2, 2016, from Türkçe Bilgi: http://www.turkcebilgi.com/eposta

Türkoğlu, S. (2013). Ergenlerin Problemli İnternet Kullanımlarn ile Siber Zorbalık Eğilimleri Arasındaki İlişkinin İncelenmesi. İstanbul: Yüksek Lisans Tezi. Marmara Üniversitesi Eğitim Bilimleri Enstitüsü Bilgisayar ve Öğretim Teknolojileri Eğitimi Ana Bilim Dalı Bilgisayar ve Öğretim Teknolojileri Eğitimi Bilim Dalı.

Usta, A. (2016). Üstün Zekalı ve Yetenekli Öğrencilerde İnternet Bağımlılığının Farklı Değişkenlere Göre İncelenmesi. Konya: Necmettin Erbakan Üniversitesi Eğitim Bilimleri Enstitüsü Özel Eğitim Ana Bilim Dalı Özel Eğitim Bilim Dalı.

Uzun, Ö. (2011). İnternet Bă̆ımlılı̆̆ı. Retrieved Nisan 2, 2016, from Gündem Psikiyatri: http://gundempsikiyatri.com/internetbagimliligi.htm

Uzunoğlu, E., Onat, F., Alikılıç, Ö. A., \& Çakır, S. Y. (2009). İnternet Çă̆ında Kurumsal İletişim. İstanbul: Say Yayınları. 
Üneri, Ö. Ş., \& Tanıdır, C. (2011). Bir Grup Lise Öğrencisinde İnternet Bağımlılığı Değerlendirmesi: Kesitsel Bir Çalışma. Düşünen Adam Psikiyatri ve Nörolojik Bilimler Dergisi, 265-272.

Ünsal, E. (2016). Ortaokul Öğrencilerinin İnternet Bă̆ımlılığının Bazı Değiş̧kenlere Göre İncelenmesi. İstanbul: Nişantaşı Üniversitesi Sosyal Bilimler Enstitüsü.

Vikipedi. (2014, Temmuz 8). Paket anahtarlama. Retrieved Ocak 31, 2016, from https://tr.wikipedia.org/wiki/Paket_anahtarlama

Vikipedi. (2016, Ocak 8). Retrieved Ocak 31, 2016, from https:/tr.wikipedia.org/wiki/\%C4\%B0leti\%C5\%9Fim

Vikipedi. (2016, Mart 23). World Wide Web. Retrieved Nisan 1, 2016, from Wikipedia: https://tr.wikipedia.org/wiki/World_Wide_Web

Vural, Z. A., \& Bat, M. (2010). Yeni bir iletişim ortamı olarak sosyal medya: Ege Üniversitesi İletişim Fakültesi'ne yönelik bir araştırma. Journal of Yaşar University, 20(5), 3348-3382.

Waldo, A. D. (2014). Correlates of Internet Addiction Among Adolescents. Psychology, 1999-2008.

Wang, H., Zhou, X., Lu, C., Wu, J., Deng, X., \& Hong, L. (2011). Problematic internet use in high school students in Guangdong Province, China. Open-Acces, 6(5), 1-8.

Watson, J. C. (2005). Internet Addiction Diagnosis and Assessment:Implications for Counselors. Journal of Professional Counseling: Practise, Theory, E Research, 17-30.

West, R. (2001). Theories of Addiction. Addiction(96), 3-13.

Whang, L. S.-M., Lee, S., \& Chang, G. (2003). Internet over-users' psychological profiles: A behavior sampling analysis on internet addiction. CyberPsychology and Behavior, 6(2), 143-150.

Widyanto, L., \& Griffiths, M. (2006). 'Internet Addiction': A Critical Review. International Journal of Mental Health and Addiction, 31-51.

Winekol. (2015). Retrieved Nisan 1, 2016, from Winekol: https://winekol.com/urunler/online-konferans/

Worldmeters. (2017, Haziran 1). Worldmeters. Retrieved Mart 15, 2016, from http://www.worldometers.info/tr/

Wu, Y. T., \& Tsai, C. C. (2006). University Students' Internet Attidues and Internet Self-Efficacy: A Study at Three Universities in Taiwan. CyberPsychology and Behavior, 9(4), 441-450.

Yakın, M. (2006). Bilgi İletişim Teknolojileri ve Medya. In B. A. Vural, Bilgi İletişim Teknolojileri ve Yansımaları (pp. 18-19). Ankara: Nobel.

Yalçın, C. (2003). Sosyolojik bir bakış açısıyla internet. Cumhuriyet Üniversitesi Sosyal Bilimler Dergisi, 77-89.

Yalçın, N. (2006). İnterneti doğru kullanıyor muyuz? İnternet bağımlısı mıyız? Çocuklarımız ve gençlerimiz risk altında $m \imath$ ? Ankara: Gazi Üniversitesi Endüstriyel Sanatlar Eğitim Fakültesi.

Yalın, H. İ. (2008). İnternet Temelli Ĕ̆itim. Ankara: Nobel Yayıncılık.

Yalın, H. İ. (2015). Öğretim Teknolojileri. Ankara: Nobel.

Yang, S. C., \& Tung, C.-J. (2007). Comparison of internet addicts and non-addicts in taiwanese high school. Computer in Human Behaviour(23), 79-96.

Yen, J.-Y., Yen, C.-F., Chen, C.-C., Chen, S.-H., \& Ko, C.-H. (2007). Family factor of internet addiction and substance use experience in Taiwanese Adolescents. Cyber Psychology and Behavior, 10(3), 323-329.

Yıldız, İ. (2010). Lise Öğrencilerinde Problemli İnternet Kullanımı İle Să̆glıkı Yaşam Biçimi Davranışları Arasındaki İlişki. Sivas: Cumhuriyet Üniversitesi Sağlık Bilimleri Enstitüsü. 
Yılmaz, E. (2013). Lise 9. ve 10. sınıföğrencilerinin internet bağımlılı düzeyleri ile problem çözme becerileri arasındaki ilişkinin çeşitli değişkenler açısından incelenmesi. İstanbul: Marmara Üniversitesi Eğitim Bilimleri Enstitüsü.

Yılmaz, E. (2013). Lise 9. ve 10. Sinıf Sımı Öğrencilerinin İnternet Bağımlılık Düzeyleri ile Problem Çözme Becerileri Arasındaki İlişkinin Çeşitli Değişkenler Açısından İncelenmesi. İstanbul: Marmara Üniversitesi Eğitim Bilimleri Enstitüsü, Yayımlanmamış Yüksek Lisans Tezi.

Yılmaz, S. (2006). Internet ve internet kafelerin ilk ve ortaöğretim öğrencilerine etkileri, yayımlanmamış yüksek lisans tezi. Sakarya: Sakarya Üniversitesi Sosyal Bilimler Enstitüsü Sosyoloji Anabilim Dalı.

Young, K. S. (1996). Internet addiction: The emergence of a new clinical disorder. CyberPsychology and Behavior, 237-244.

Young, K. S. (1999). İnternet Addiction: Symptoms, Evaluation, And Treatment. Innovations in Clinical Practice.

Young, K. S. (2004). Internet Addiction A New Clinical Phenomenon and Its Consequences. AMERICAN BEHAVIORAL SCIENTIST,, 402-415.

Young, K. S. (2009). Assessment and Treatment of Internet Addiction. In The Praeger International Collection on Addictions (pp. Vol4,part3 217-235). Greenwood Publishing Group.

Young, K. S. (2009). Internet Addiction: Diagnosis and Treatment Considerations. J Contemp Psychother, 241246.

Young, K. S. (2015). Parenting in the Digital Age: Strategies and Prevention. Retrieved 1 11, 2015, from Net Addiction: http://netaddiction.com/childrenonline/

Young, K. S., \& de Abreu, C. N. (2011). Internet addiction: A handbook and guide to evaluation and treatment. (K. Young, \& C. Nabuco de Abreu, Eds.) New Jersey: John Wiley \& Sons, Incorporation.

Young, K. S., \& Rodgers, R. C. (1998). The Relationship Between Depression and Internet Addiction. CyberPsychology and Behavior, 1(1), 25-28.

Young, M. L. (1999). Internet: The complete reference. New York: The McGraw-Hill.

Yu, L., \& Shek, D. T. (2013). Internet addiction in Hong Kong adolescents: A three-year longitudinal study. Journal of Pediatric and Adolescent Gynecology, 26(3), 10-17.

Yücelten, E. (2016). Üniversite Öğrencilerinde İnternet Bağımlılı̆̆ı ve Akıllı Telefon Bağımlılığının Bağlanma Stilleri ile İlişkisinin İncelenmesi. İstanbul: Üsküdar Üniversitesi Sosyal Bilimler Enstitüsü Klinik Psikoloji Ana Bilim Dalı.

Yüksel, H. (2014). İletişimin Tanımı ve Temel Bileşenleri. In U. Demiray, Etkili İletişim (pp. 4-7). Ankara: Pegem Akademi.

Yükseltürk, E., \& Top, E. (2016). Web 2.0 Teknolojilerinin Öğretmen Eğitimde Kullanımı. In K. Çağıltay, \& Y. Göktaş, Öğretim Teknolojilerinin Temelleri (pp. 555-556). Ankara: Pegem Akademi.

Zorbaz, O. (2013). Lise Öğrencilerinin Problemli İnternet Kullanımının Sosyal Kaygı ve Akran İlişkileri Açısından İncelenmesi. Ankara: Hacettepe Üniversitesi Sosyal Bilimler Enstitüsü. 